Paleoenvironmental proxies and what the Xiamaling Formation tells us about the midProterozoic ocean

Zhang, Shuichang; Wang, Xiaomei; Wang, Huajian; Bjerrum, Christian J.; Hammarlund, Emma U.; Haxen, Emma R.; Wen, Hanjie; Ye, Yuntao; Canfield, Donald E.

Published in:

Geobiology

DOI:

10.1111/gbi.12337

Publication date:

2019

Document version

Peer reviewed version

Citation for published version (APA):

Zhang, S., Wang, X., Wang, H., Bjerrum, C. J., Hammarlund, E. U., Haxen, E. R., Wen, H., Ye, Y., \& Canfield, D. E. (2019). Paleoenvironmental proxies and what the Xiamaling Formation tells us about the mid-Proterozoic ocean. Geobiology, 17(3), 225-246. https://doi.org/10.1111/gbi.12337 


\section{Paleoenvironmental proxies and what the Xiamaling Formation tells us about the mid-Proterozoic ocean}

Shuichang Zhang', Xiaomei Wang ${ }^{1}$, Huajian Wang ${ }^{1}$, Christian J. Bjerrum ${ }^{2}$, Emma

U. Hammarlund ${ }^{3,4}$, Emma R. Haxen ${ }^{2}$, Hanjie Wen ${ }^{5}$, Yuntao Ye ${ }^{1}$, Donald E. Canfield $^{1,3}$

1) Key Laboratory of Petroleum Geochemistry, Research Institute of Petroleum Exploration and Development, China National Petroleum Corporation, Beijing 100083, China

2) Department of Geoscience and Natural Resource Management, University of Copenhagen, Øster Voldgade 10, 1350 Copenhagen K, Denmark

3) Nordcee, Institute of Biology, University of Southern Denmark, Campusvej 55, 5230 Odense $M$, Denmark

4) Lund University, Translational Cancer Research, Medicon Village 404:C3, Scheelevägen 2, 22381 Lund, Sweden

5) State Key Laboratory of Ore Deposit Geochemistry (SKLODG), Institute of Geochemistry, Chinese Academy of Sciences, Guiyang 550002, China

Corresponding author: Don Canfield; dec@biology.sdu.dk

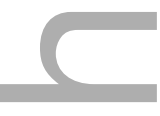

Acknowledgments: the authors wish to acknowledge generous funding from the Villum Fund (grant 16518), the Danish Free Natural Science Foundation (4181-00025), and J. McManus for kindly making available geochemical data from the California Borderland Basins and Mexican Borderland. We also acknowledge generous funding from State Key National Natural Science Foundation of China (41530317), National Science and Technology Major Project (2016ZX05004-001), and the Scientific Research and This is the author manuscript accepted for publication and has undergone full peer review but has not been through the copyediting, typesetting, pagination and proofreading process, which may lead to differences between this version and the Version of Record. Please cite this article as doi: 10.1111/GBI.12337

This article is protected by copyright. All rights reserved 
Technological Development Project of China National Petroleum Corporation (CNPC 2016A-0204, 2016A-0205), the Strategic Priority Research Program of the Chinese Academy of Sciences (XDA14010101).

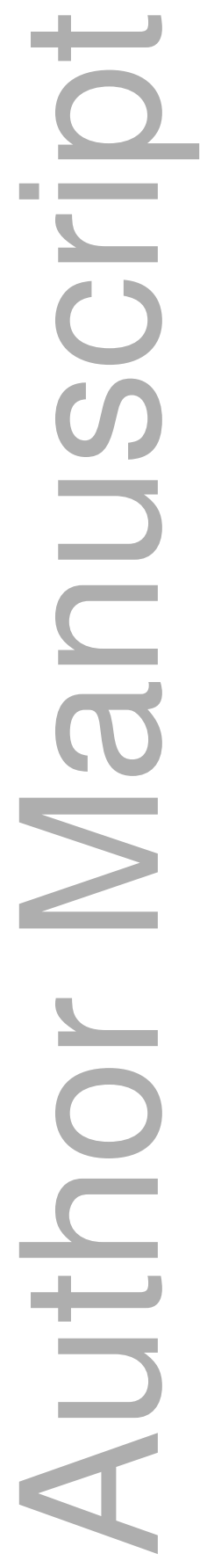

This article is protected by copyright. All rights reserved 


\title{
Paleoenvironmental proxies and what the Xiamaling Formation tells us about the mid-Proterozoic ocean
}

\author{
Corresponding author: Don Canfield; dec@ biology.sdu.dk
}

Abstract

The Mesoproterozoic Era (1600 to 1000 million years ago, Ma) geochemical record is sparse, but nevertheless, critical in untangling relationships between the evolution of eukaryotic ecosystems and the evolution of Earth-surface chemistry. The ca. 1400 Ma Xiamaling Formation has experienced only very low-grade thermal maturity and has emerged as a promising geochemical archive informing on the interplay between climate, ecosystem organization, and the chemistry of the atmosphere and oceans. Indeed, the geochemical record of portions of the Xiamaling Formation have been used to place minimum constraints on concentrations of atmospheric oxygen as well as possible influences of climate and climate change on water chemistry and sedimentation dynamics. A recent study has argued, however, that some portions of the Xiamaling Formation deposited in a highly restricted environment with only limited value as a geochemical archive. In this contribution we fully explore these arguments as well as the underlying assumptions surrounding the use of many proxies used for paleo-environmental reconstructions. In doing so, we pay particular attention to deep-water oxygen-minimum zone environments and show that these generate unique geochemical signals that have been underappreciated. These signals, however, are compatible with the geochemical record of those parts of the Xiamaling Formation interpreted as most restricted. Overall, we conclude that the Xiamaling Formation was most likely open to the global ocean throughout its depositional history. More broadly, we show that proper paleo-environmental reconstructions require an understanding of the biogeochemical signals generated in all relevant modern analogue depositional environments. We also evaluate new data on the $\delta^{98}$ Mo of Xiamaling Formation shales, revealing possible unknown pathways of molybdenum sequestration into sediments and concluding, finally, that seawater at that time likely had a $\delta^{98}$ Mo value of about 1.1 $\%$.

\section{Introduction}

The Mesoproterozoic Era is emerging as a critical, but poorly understood, time in Earth history. This time interval witnessed the emergence of nascent eukaryote ecosystems (Cohen \& Macdonald, 2015 ; Knoll et al., 2006 ; Knoll, 2014), that did not, however, come to prominence until much 
later in the Cryogenian Period (720 to $635 \mathrm{Ma}$ ) of the Neoproterozoic Era (1000 to $541 \mathrm{Ma}$ ) (Brocks et al., 2017) when oxygen may have risen to higher levels (Canfield \& Teske, 1996 ; Scott et al., 2008 ; Canfield, 2014 ; Lyons et al., 2014). One possible explanation for the lack of eukaryote dominance during the Mesoproterozoic Era is low oxygen concentrations that could have hindered the respiratory requirements of early eukaryotic organisms including both animals and algae (Knoll, 2011; Knoll \& Nowak, 2017 ; Knoll, 1992b ; Nursall, 1959 ; Berkner \& Marshall, 1965 ; Knoll, 1992a). Another hindrance on eukaryote evolution could have been sulfide toxicity resulting from expanded anoxic-sulfidic waters in a low-oxygen atmosphere (Anbar \& Knoll, 2002), or the limiting of bio-essential trace metals in a more sulfidic Mesoproterozoic marine environment (Dupont et al., 2010).

Thus, there are many suggestions of a relationship between environmental chemistry and the pace and timing of eukaryote evolution, and many approaches can be used to test for the validity of these possible relationships. One approach is physiological, where the chemical controls on organismal respiration and growth are explored (Mills et al., 2014 ; Mills et al., 2018), directly defining the oxygen tolerance of different organisms. In another approach, comparative biology can explore both closely and distantly related organisms to uncover ancestral traits whose emergence might possibly be accounted for by environmental drivers (Knoll \& Nowak, 2017 ; Knoll \& Carroll, 1999 ; Towe, 1970 ; Knoll \& Hewitt, 2011). Another approach is phylogenetic, where the timing and nature of major evolutionary events is determined from the molecular sequence data of organisms calibrated against the fossil record to produce molecular clocks (Erwin et al., 2011 ; Dohrmann \& Wörheide, 2017 ; Parfrey et al., 2011). This leads to the last approach, which is the rock record itself, providing a direct fossil record of ancient organismal evolution and also of geochemical clues as to the chemical nature of ancient ecosystems (Knoll, 1992b ; Knoll, 1992a ; Lyons et al., 2014 ; Raiswell \& Canfield, 2012 ; Canfield, 2014 ; Canfield et al., 2008).

Unfortunately, the sedimentary rock record during the Mesoproterozoic Era has not been well studied, and any preserved sediments, particularly well-preserved sediments, become of great importance. The best-preserved of these are from the Roper Group of the McArthur Basin of northern Australia and from the Yanliao rift system of the North China Craton. The sedimentary rocks of the Roper Group, and particularly the ca. 1400 Velkerri Formation, have been instrumental in providing early molybdenum isotope evidence for expanded Mesoproterozoic Era marine sulfidic conditions (Arnold et al., 2004). These sedimentary rocks have also provided the earliest evidence for marine anoxygenic phototrophic communities (Brocks et al., 2005) as well as a detailed record 
of trace-metal availability at this time in Earth history (Cox et al., 2016). The ca. $1560 \mathrm{Ma}$ Gaoyuzhuang Formation from the Yanliao rift of the North China Craton has revealed fossil evidence for early eukaryote multi-cellularity (Zhu et al., 2016), and additional biogeochemical evidence for expanded ocean-water oxygenation contemporaneous with the eukaryotic fossils (Zhang et al., 2018).

The somewhat younger ca. 1390 Ma Xiamaling Formation, also from the Yanliao rift, has provided a rich repository of geochemical information. The Xiamaling Formation geochemical record has revealed sedimentation patterns consistent with Milankovich periodicity (Zhang et al., 2015b). The record has also revealed water-column conditions ranging between oxygenated, sulfidic and ferruginous (Wang et al., 2017 ; Zhang et al., 2017 ; Diamond et al., 2018), with evidence in some parts of the stratigraphy for an oxygen-minimum zone setting (OMZ) with oxygenated bottom waters (Zhang et al., 2016). Another part of the succession houses the largest known iron formation (IF) in the Mesoproterozoic Era (Canfield et al., 2018 ; Zhu et al., 2013 ; Zhang \& Zhu, 2013a ; Zhang \& Zhu, 2013b). Where bottom water oxygenation has been identified in the Xiamaling Formation, biogeochemical modeling has revealed that atmospheric oxygen concentrations were likely > 4-6\% of present-day values (Zhang et al., 2016 ; Zhang et al., 2017).

Evaluations of ancient atmospheric and ocean chemistry from the rock record depend critically on the nature of the ancient depositional environment. For example, one cannot necessarily apply the geochemical proxies developed from modern marine sediments to sediments deposited in an ancient lake environment. In this regard, and based on the behavior of a variety of geochemical proxies, the Xiamaling Formation has recently been interpreted as a closed-basin environment with similarities to an ancient lake (Diamond et al., 2018). If correct, the Xiamaling Formation is of less value in illuminating ancient marine and atmosphere chemistry, and some of the previous interpretations may, indeed, be incorrect. In this paper, we review the biogeochemical proxies used to establish the Xiamaling Formation depositional environment. We explore the underlying assumptions associated with use of these proxies, and we highlight the geochemical record left in modern OMZ settings. We conclude that all proxies in the Xiamaling Formation are consistent with a depositional setting open to the marine environment. We identify previously unappreciated structure to the chemistry of the ancient Xiamaling depositional basin. Finally, we analyze a new molybdenum isotope $\left(\delta^{98} \mathrm{Mo}\right)$ database, recognizing possible unknown pathways of Mo acquisition by sediments. We also 
conclude that at the time the Xiamaling Formation deposited, seawater most likely had a $\delta^{98}$ Mo of about $1.1 \%$, similar to previous estimates for around this time (Arnold et al., 2004).

\section{Methods}

Our discussion is mainly based on the interpretation of already published geochemical data. However, we have also generated a new data set on the $\delta^{98}$ Mo of Xiamaling Formation rocks. These data were obtained from previously described core and outcrop samples collected in the Xiahuayuan region of the North China Craton (Figure 1) (Zhang et al., 2015b ; Wang et al., 2017 ; Zhang et al., 2017). Our analyzed samples range through units 1, 2, 3 and 4 of the Xiamaling Formation as described below. See Wang et al. (2017) for specific details of our sampling locations.

The analytical methods for determining Mo isotopes have been detailed by Zhang et al. (2009b) and (Wen et al., 2010; Wen et al., 2011). Briefly, after determining Mo concentrations, sample powders with an equivalent of $>100 \mathrm{ng}$ Mo were oxidized at $600^{\circ} \mathrm{C}$ for $8 \mathrm{~h}$, and then transferred to a Teflon beaker. Before digestion with acid, an adequate amount (1:1 sample to spike) of the ${ }^{100} \mathrm{Mo}+{ }^{97} \mathrm{Mo}$ double-spike was added to account for any Mo isotope fractionation during column separation and to resolve instrumental mass bias. Samples were digested using a mixture of $\mathrm{HF}$ and $\mathrm{HNO}_{3}(1: 2)$ at $100^{\circ} \mathrm{C}$ for at least $16 \mathrm{~h}$ until the samples were completely dissolved. An improved anion/cation exchange resin double-column procedure was used to separate Mo from natural samples as described in Zhang et al. (2009b). This method yields recovery of Mo of $97.49 \pm 0.27 \%$. Potential interferences on Mo isotopes, including $\mathrm{Zr}, \mathrm{Fe}, \mathrm{Mn}$ and other interfering matrix elements were present at negligible levels relative to Mo.

Mo isotopic measurements were performed on the Thermo-Fisher Scientific Neptune Plus MC-ICP-MS (Thermo Fisher Scientific, Germany) at the SKLODG, IGCAS. Signal acquisition was performed according to the following collector configurations: ${ }^{91} \mathrm{Zr}^{+},{ }^{94} \mathrm{Mo}^{+},{ }^{95} \mathrm{Mo}^{+},{ }^{96} \mathrm{Mo}^{+}$, ${ }^{97} \mathrm{Mo}^{+},{ }^{98} \mathrm{Mo}^{+},{ }^{99} \mathrm{Ru}^{+}$, and ${ }^{100} \mathrm{Mo}^{+}$ion beams were collected by Faraday cups at Low 4, Low 2, Low 1, Central, High 1, High 2, High 3 and High 4 positions, respectively. One block of 60 cycles were measured at each amu. At an uptake rate of $\sim 50 \mu \mathrm{l} / \mathrm{min}, 2 \%(\mathrm{v} / \mathrm{v}) \mathrm{HNO}_{3}$, was used to introduce $200 \mathrm{ng} / \mathrm{L}$ Mo sample and reference solutions into the mass spectrometer. The typical Mo sensitivity achieved was $\sim 60 \mathrm{~V} / \mathrm{ppm}$. After each run, 5\% (v/v) $\mathrm{HNO}_{3}$ was aspirated through the sample-introduction system to prepare for the next sample.

During an analytical session, the reference solution was measured as a sample after each batch of three samples to control for the stability and accuracy of Mo isotope measurement. The 
reference solution was NIST SRM 3134 (lot\#891307) with the ${ }^{100} \mathrm{Mo}+{ }^{97}$ Mo double-spike (1:1). Since Nägler et al. (2014) suggested that the $\delta^{98 / 95}$ Mo value of NIST SRM 3134 was better to set as $0.25 \%$, calculation of the final $\delta^{98 / 95}$ Mo values relative to the NIST SRM $3134=0.25 \%$ could be defined by the following relationship:

$$
\delta^{98 / 95} \mathrm{Mo}(\% \mathrm{o})=\left(\frac{\left({ }^{98} \mathrm{Mo} /{ }^{95} \mathrm{Mo}\right)_{\text {sample }}}{\left({ }^{98} \mathrm{Mo} /{ }^{95} \mathrm{Mo}\right)_{\text {NIST } 3134} * 0.99975}-1\right) * 1000 .
$$

Repeated measurements of a pure NIST SRM 3134 Mo solution and a mixture of NIST SRM 3134 Mo solution and ${ }^{100} \mathrm{Mo}+{ }^{97} \mathrm{Mo}$ double spike (1:1) yielded a reproducibility of better than $\pm 0.09 \%$ $(2 \sigma)$ and $\pm 0.06 \%$ (2б), respectively, in the $\delta^{98}$ Mo value. Two artificially fractionated Mo solutions (SC2 and SC3) of Sigma-Aldrich Mo (lot\#207306) yielded a mean $\delta^{98}$ Mo value of $1.59 \pm 0.09 \%$ $(2 \sigma, \mathrm{n}=12)$ and $-1.68 \pm 0.06 \%$ o $(2 \sigma, \mathrm{n}=10)$, respectively, consistent with the reported values $1.67 \%$ and $-1.63 \%$ (Wen et al., 2010). Two in-house rock standards also were analyzed to evaluate the effect of the ${ }^{100} \mathrm{Mo}+{ }^{97} \mathrm{Mo}$ double spike for calibrating mass bias during anion/cation exchange chromatography and isotope measurement. $\delta^{98}$ Mo values of the Limestone standard (GSR-6,

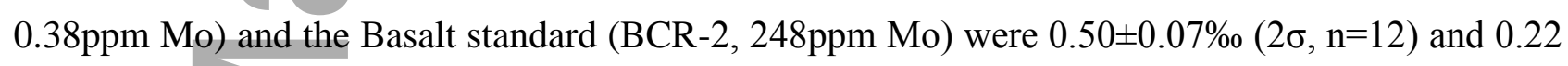
$\pm 0.09 \%$ o $(2 \sigma, \mathrm{n}=12)$, respectively, which is consistent with the recommended values. The results corrected by the double diluted (DS) method and standard sample bracketing (SSB) method were within error consistent with each other, and the external reproducibility was better than $\pm 0.10 \%$ for $\delta^{98}$ Mo. Duplicate and triplicate samples were also analyzed with an overall reproducibility better than $\pm 5 \%$ for Mo concentration and $\pm 0.10 \%$ (0.08- 0.13$)$ for $\delta^{98}$ Mo values was achieved.

\section{The development of the Yanliao Rift system}

Xiamaling Formation is part of a thick Meso-Neoproterozoic Era sedimentary sequence deposited on igneous rocks formed, most likely, as a consequence of continent-continent collision during the assembly of supercontinent Columbia (Nuna) (Hu et al., 2016 ; Meng et al., 2011a). The sedimentary rocks of the Changcheng system in the Yanliao rift were deposited directly on the crystalline rocks (Figure 1). Within the Changcheng system, a series of 1640 to 1620 Ma mafic dikes within the Chuanlinggou Formation (Figure 1) (Zhang \& Zhao, 2016), as well as similarly aged eruptive volcanic rocks in the Dahangyu Formation (Figure 1) (Wang et al., 2015), provide 
evidence for the initiation of intracontinental rifting, and the development of the Yanliao rift. This rifting, together with other rift basins in the North China Craton, represent the initial breakup stages of supercontinent Columbia (Nuna) (Zhang et al., 2015a ; Zhang \& Zhao, 2016). The Yanliao rift, however, did not develop into the drift phase and was thus aborted (Zhang \& Zhao, 2016).

The overlying Jixian system starts with the Gaoyuzhuang Formation that lies both conformably and unconformably over the underlying Dahongyu Formation, where exposure of the Dahongyu Formation was a likely consequence of a marine regression (Figure 1) (Qu et al., 2014). Overall, the Jixian System deposited over a time span of about 130 million years (Figure 1), and during a period of relative tectonic quiescence (Zhang \& Zhao, 2016). Occasional depositional hiatuses have been observed between some of the formations in the Jixian System, but these have been regarded a result of eustatic sealevel change and not episodes of regional uplift (Qu et al., 2014).

The Tieling Formation is the top unit of the Jixian System (Figure 1). The upper parts of the Tieling Formation are dominated by stromatolitic limestone deposited, most likely, in a subtidal environment above storm wave base (Tang et al., 2017 ; Meng et al., 2011b). The Xiamaling Formation deposited on top of the Tieling Formation, but it is not recognized as part of the Jixian System because a widespread unconformity marks the boundary between the Tieling and Xiamaling Formations (Qu et al., 2014). The unconformity is attributed to an uplift event known as the Qinyu movement, and in some locations, particularly in the western part of the basin, a significant weathering crust separates the two formations (Qu et al., 2014). In contrast, in the region of Pingquan (Figure 1), the contact is conformable (Qu et al., 2014). In one hypothesis, the Qinyu movement was a result of back-arc uplift related to subduction initiated during the late stages of Tieling Formation deposition (Qu et al., 2014). In this model, subsequent back-arc extension generated basin subsidence and thus the depositional setting for the deep-water facies of the Xiamaling Formation.

The hypothesis of back-arc uplift has been supported by the occurrence of bentonites in the middle levels of the Xiamaling Formation (Qu et al., 2014 ; Qiao et al., 2008) (Figure 1). The origin of these bentonites has not been identified (Zhang \& Zhao, 2016), but they occur well after the Qinyu uplift and well after the basin subsidence allowing for the deposition of the Xiamaling Formation. It seems unlikely, therefore, that these volcanics could reflect processes contributing to uplift and the sub-aerial emergence of the Tieling Formation, although they could conceivably be related to backarc basin extension during deposition of the Xiamaling Formation. 
A series of diabase sills dated to around $1320 \mathrm{Ma}$ intrude the Xiamaling Formation at various locations (Figure 1), and these represent what is likely a large igneous province (LIP) generated during the further breakup of supercontinent Columbia (Zhang \& Zhao, 2016). While these intrusives are clearly related to tectonic activity, they postdate the deposition of the Xiamaling Formation and thus do not support an extensional back-arc setting during Xiamaling Formation deposition. Overall, Qu et al. (2014) conclude that while the trench-arc-basin hypothesis is worthy of consideration, there are no independent data to support it.

New evidence, however, does point to active tectonics during early stages of the Xiamaling Formation deposition. An iron formation (IF) has recently been described as unit 5 (Canfield et al., 2018 ; Zhang \& Zhu, 2013a ; Zhang \& Zhu, 2013b ; Tang et al., 2018) (Figure 2), and the sedimentology of this IF is consistent with mass flow events that could have been triggered by tectonic shocks (Canfield et al., 2018). In addition, the bottom of the IF contains iron-rich sedimentary rocks that appear to have undergone brittle deformation possibly during mud-slide events (Canfield et al., 2018). Several bentonite layers have also been discovered within these ironrich rocks (Tang et al., 2018), consistent with active tectonics during deposition of this part of the Xiamaling Formation. But, this episode of active tectonics does not explain the processes leading to the sub-aerial emergence of the Tieling Formation, or the subsequent subsidence of the basin allowing the deposition of the Xiamaling Formation. These processes occurred earlier, and their driver remains an open question.

\section{The Xiamaling Formation}

As noted above, the Xiamaling Formation deposited both conformably and unconformably on the underlying Tieling Formation of the Jixian System. The Xiamaling Formation is spread over an area of about $60,000 \mathrm{~km}^{2}$ (Fan, 2015), but its original dimensions may have been much larger, especially to the north, where connections to the Zhaertal-baiyun'ebo rift in today's Mongolia (Figure 1) have possibly been eroded due to uplift and denudation (Qu et al., 2014). The connections between the Xiamaling Formation and the open ocean were also likely to the North (Qu et al., 2014 ; Hu et al., 2016), although this connection is not preserved and, overall, the paleogeography of the North China Craton during Xiamaling Formation times is poorly known. 
In describing the Xiamaling Formation, we will follow the stratigraphic framework for the Xiahuayuan region as presented in Wang et al. (2017) (Figure 2). The lowermost Xiamaling Formation comprises unit 6 in this stratigraphic scheme, and the sedimentary rocks contacting the underlying Tieling Formation are either conglomerates, ferruginous sandstones or ferruginous sandy shales depending on the location (Qu et al., 2014). In the region of Xiahuayuan, the lower part of unit 6 deposited in shallow waters where sands are frequently cross laminated showing evidence of wave impingement on the sediment surface (Wang et al., 2017). Unit 5 houses the Xiamaling IF and has been well described in sections from both the Xiahuayuan and Jixian regions (Figure 1) (Canfield et al., 2018; Zhang \& Zhu, 2013a ; Zhang \& Zhu, 2013b ; Tang et al., 2018). However, siderite-rich layers that may represent unit 5 have been noted in sections throughout the basin (Fan, 2015). The Xiamaling IF contains an estimated $520 \mathrm{Gt}$ of authigenic iron (with the present dimensions of the Xiamaling Formation) and represents the largest-known Mesoproterozoic Era IF (Canfield et al., 2018). The Xiamaling IF is composed mainly of siderite with minor ironsilicate phases like glauconite (Canfield et al., 2018). As described above, sedimentation in unit 5 is sometimes represented by mass flows and even brittle deformation (Canfield et al., 2018), with the possible influence of tectonic shocks, but there is no evidence for cross laminations resulting from wave impingement on the sediment surface (Canfield et al., 2018). Therefore, this unit appears to have deposited in waters below storm wave base. Indeed, in the region of Xiahuayuan there is no evidence for wave impingement on the sediment surface from unit 5 until the top of unit 1. Therefore, the Xiamaling Formation represents a deep-water environment through most of its depositional history.

Unit 4 is best described in the region of Xiahuayuan, and here, it is characterized by frequent turbidites interrupting the background sedimentation of ferric iron-enriched silty muds (Wang et al., 2017) yielding distinct red-green banding in the rocks. The background silts are organic poor with a low hydrogen index (HI) indicating extensive organic matter mineralization. This unit has been interpreted as a low productivity OMZ depositional environment with anoxic ferruginous waters at intermediate depth overlying oxygenated bottom waters (Wang et al., 2017).

Moving up section in unit 4, there is a gradual transition where the red layers disappear, as do the turbidites, and thin organic-rich shales mark the beginning of unit 3 . Unit 3 is widespread, having also been reported in the regions of Xiahuayuan, Chicheng, and Beijing, while black shales that could be unit 3 have been described from Zhaojiashan, 
Mentougou, Yanqing, Xingiong, and Kuancheng (Diamond et al., 2018 ; Fan, 2015 ; Wang et al., 2017 ; Zhang et al., 2015b ; Zhang et al., 2016) (see Figure 1 for location map). At Xiahuayuan, where unit 3 is best described, it is characterized by regular alterations between organic-rich shales and organic-poor cherty units (Wang et al., 2017 ; Zhang et al., 2015b; Zhang et al., 2016). With high-precision dating, the frequency of these alterations was found to correspond to expected periods of procession, obliquity and eccentricity (Zhang et al., 2015b). Therefore, sedimentation in unit 3 appears to display signs of climate forcing.

The organic-rich shales were also unusual in that they did not display the typical combined enrichments in the redox-sensitive trace metals vanadium (V), molybdenum (Mo) and uranium $(\mathrm{U})$ as would be expected under deposition in an anoxic environment (Zhang et al., 2016). The only sediment environment in the modern ocean where such poor trace metal enrichments are found in association with high TOC concentrations is the oxygenated waters depositing beneath an OMZ (Zhang et al., 2016 ; Wang et al., 2017 ; Nameroff, 2002). Thus, combined with biomarker evidence for the presence of anoxygenic phototrophic bacteria, unit 3 was interpreted to represent the oxygenated waters below an ancient OMZ (Zhang et al., 2016). These observations inspired a simple ocean model whose results suggested a minimum oxygen concentration of $4 \%$ of present-day levels (PAL) during the deposition of unit 3 (Zhang et al., 2016). The interpretation of an ancient OMZ setting for unit 3 will be explored in more detail below.

In the region of Xiahuayuan, the top of unit 3 shows a return to organic-poor green shales with frequent carbonate concretions, but after about $20 \mathrm{~m}$, black shales develop, signaling the beginning of unit 2 (Wang et al., 2017). With a total thickness of about $200 \mathrm{~m}$, unit 2 black shales represent about half of the Xiamaling Formation stratigraphy at Xiahuayuan (Figure 2). Using a variety of proxies (explored in more detail below), the lower shales of unit 2 at Xiahuayuan most likely deposited in a ferruginous anoxic environment, while the upper shales (the upper $30 \mathrm{~m}$ ) probably deposited in an euxinic depositional setting (Wang et al., 2017). In contrast, and as discussed more fully below, in the region of Chicheng, the shales at the bottom of unit 2 appear to have deposited in an euxinic setting (Diamond et al., 2018). In our samples from the Xiahuayuan region, there is a gap of about $75 \mathrm{~m}$ in the middle of the unit that was buried too deep in the subsurface for access by coring. The geochemistry of rocks represented within this gap has not been evaluated, but at 
Xiahuayuan, the transition between ferruginous and euxinic depositional conditions occurs within this gap.

The transition between unit 2 and unit 1 is gradual, and the boundary between these units has been taken as the first appearance of organic-poor, trace metal-poor green shales that are infrequent at first, but become more frequent moving up stratigraphy (Wang et al., 2017 ; Zhang et al., 2017). The green shales and black shales of unit 1 represented two different geochemical environments, and the geochemical indicators are consistent with the green shales deposited in oxygenated waters and the black shales deposited in anoxic waters, a mix between ferruginous and euxinic conditions (Wang et al., 2017; Zhang et al., 2017). The transition between the green and black shale units may have also been climate controlled (Zhang et al., 2015b). By comparing the organic geochemical characteristics of unit 1 with modern environments, a simple sediment diagenetic model was constructed reproducing the differences in carbon preservation between the green and black shale units (Zhang et al., 2017). These differences were argued to arise from enhanced oxic degradation of organic matter in the green shales requiring, according to modelling results, a minimum of 4\% PAL oxygen (Zhang et al., 2017).

Therefore, the Xiamaling Formation had a complex depositional history, but with unique geochemical records relevant for documenting aspects of ancient climate, ocean chemistry, and ancient atmospheric oxygen levels.

\section{Alternative views of the Xiamaling Formation}

Diamond et al. (2018) have recently published geochemical results from a Xiamaling Formation core from the Chicheng region (this publication states that the coring site is in the Xiahuayuan region, but their map shows the core from the Chicheng region, some $100 \mathrm{~km}$ to the Northeast of Xiahuayuan; we assume that the map is correct). A detailed sedimentology of this core was not presented, and neither was the stratigraphy of the Xiamaling Formation in this area. We are also unaware of any stratigraphic descriptions in the literature. However, this core appears to represent lower unit 2 and unit 3 of the Xiamaling Formation in the Xiahuayuan region (Figure 2) (Diamond et al., 2018). The study of Diamond et al. (2018) explored a variety of geochemical proxies to conclude, in contrast to previous work, that basin restriction became so extreme during periods of Xiamaling Formation deposition as to dramatically limit the availability of key seawater constituents like sulfate, trace metals, and reactive iron. It was further argued that because of this basin restriction, previous conclusions on the depositional environment of the Xiamaling Formation 
are suspect. Equally suspect are any interpretations of atmospheric oxygen levels based on these conclusions (Diamond et al., 2018).

In what follows, we will compare the data from Diamond et al. (2018) to previously published results from the Xiahuayuan region, and will discuss each of the points raised by Diamond et al. (2018) in turn. Included also is a discussion of new Mo isotope results for units 1-4 of the Xiamaling Formation. These results will be compared with those presented by Diamond et al. (2018) and evaluated to constrain the $\delta^{98}$ Mo of seawater during the deposition of the Xiamaling Formation.

\section{Comparison of results}

The results of Diamond et al. (2018) cover one third of the total Xiamaling Formation, but in major aspects, the data are quite comparable to those previously reported (Figures 3-5). An important difference between data from the two regions is the iron speciation results. Thus, unit 3 in the Xiahuayuan region displays a wide range of FeHR/FeT values both above and below the nominal anoxic threshold of 0.38 (Raiswell \& Canfield, 2012), while in the Chicheng region, unit 3 displays very low values of FeHR/FeT, mostly ranging between 0.1 and 0.2 . Furthermore, while values of FeHR/FeT are similar in unit 2 in the two regions, both straddling and above the anoxic threshold of 0.38 (Figure 5), in Chicheng, values of FePy/FeHR are much higher than in Xiahuayuan, and are consistent with euxinic depositional conditions (Diamond et al., 2018). In Xiahuayuan, by contrast, the data are more consistent with a ferruginous depositional environment (Wang et al., 2017). The differences between the two regions provide evidence for persistent basin geochemical heterogeneity that will be discussed in more detail below.

\section{Model for basin development}

Diamond et al. (2018) state that "Following deposition of the underlying Tieling Formation, there is evidence that the shallow seaway was exposed subaerially, and our data suggest that the lower portions of the overlying Xiamaling Formation were deposited before a stable connection to the open ocean was once again established". As subaerial exposure at this time is linked to the Qinyu uplift (Qu et al., 2014), Diamond et al. (2018) seem to suggest that basin restriction resulted as a consequence of this uplift event. Diamond et al. (2018) also note that the bottom of their core (bottom of unit 3) represented a time before a "stable connection" to the open ocean was established. This would imply that severe basin restriction persisted between when the Xiamaling 
Formation began to deposit on the Tieling Formation and the deposition of unit 3 . Therefore, the history of the basin in this intervening interval becomes important.

We begin the unconformity representing the depositional boundary between the Tieling and Xiamaling Formations. If this unconformity, representing the Qinyu uplift, resulted from low-angle subduction and back-arc basin development, as has been suggested (Qu et al., 2014), then basin restriction might have occurred. However, we note that in modern back-arc settings such as the Sea of Japan and the Sea of Okhotsk, island arcs may hinder seawater flow, but the water in the basins is in good exchange with the open ocean and reflects seawater composition. Thus, a back-arc setting does not necessitate a severely restricted environment.

In the region of Xiahuayuan, 150 meters of stratigraphy separate the base of unit 3 and the initial deposition of the Xiamaling Formation on the Tieling Formation (Figures 2-5). As noted above, units below unit 3 are widely distributed and house the largest known Mesoproterozoic Era IF as well as deep-water facies of different types. The IF is of particular importance as it displays REE patterns consistent with deposition from seawater (Tang et al., 2018 ; Canfield et al., 2018), and a positive Eu anomaly suggesting a possible hydrothermal source for the iron. No local timecontemporaneous hydrothermal sources have been identified (although a series of thin bentonite layers suggests eruptive volcanism somewhere in the region (Tang et al., 2018)), and open access to a seawater iron source would seem to be required. Therefore, the idea that severe basin restriction accompanied the interval between the initial deposition of the Xiamaling Formation and the base of unit 3 does not seem to be supported. One could argue that basin restriction began and ended with unit 3 deposition. There is, however, no independent sedimentological or tectonic evidence to support this scenario.

\section{Sulfur to carbon relationships}

The relationship between carbon (TOC) and sulfur (S) has been used as critical support for the conclusion that the Xiamaling Formation deposited in a restricted environment (Diamond et al., 2018). Thus, modern "normal marine" sediments depositing under oxygenated waters contain decidedly more sulfur per unit organic carbon than sediments from fresh-water environments, where sulfate reduction is limiting due to low sulfate concentrations (Berner \& Raiswell, 1983 ; Raiswell \& Berner, 1985). Indeed, rocks from Xiamaling Formation unit 3 display very low ratios of S/C (Diamond et al., 2018) (Figure 6). These data would appear, then, to support severe sulfate limitation during pyrite formation in unit 3 , where basin restriction allowed sulfate drawn down to 
concentrations much lower than seawater values, generating carbon to sulfur trends more comparable to freshwater environments. We evaluate this argument in stages.

Implicit in this argument is that if sulfate became non-limiting, increased rates of sulfate reduction would have generated sufficient pyrite to push the $\mathrm{C} / \mathrm{S}$ relationship into the "modern marine" trend $(3 / 1)$. We can test this implication by plotting the maximum potential $\mathrm{S}$ concentration in unit 3 rocks assuming all reactive $\mathrm{Fe}$ is converted to pyrite. It is reasonable to assume that this calculation would generate maximum $\mathrm{S}$ concentrations as reactive iron is defined as that portion of $\mathrm{Fe}$ that is, or can be, formed into pyrite on early diagenetic time scales (Canfield, 1989). The extractions used to remove "reactive iron" have been also been carefully calibrated against pure and natural mineral phases, and the time scales associated with the pyritization of these phases (Canfield, 1989 ; Canfield et al., 1992; Raiswell et al., 1994 ; Poulton et al., 2004), revealing that this definition of "reactive iron" is essentially correct.

We see (Figure 6) that even if all the reactive Fe unit 3 rocks was converted to pyrite, the $\mathrm{C}$ to $\mathrm{S}$ trend would still not approach the modern "normal marin"e trend. There are likely two reasons for this: First, the amount of reactive Fe that sedimentary rocks contain varies from location to location, and even with sediment depth, depending on the mineralogy of the particles depositing onto the sediment (Raiswell \& Canfield, 1998). The rocks from unit 3 of the Xiamaling Formation have simply not deposited with sufficient reactive Fe to generate a "normal marine" $\mathrm{C} / \mathrm{S}$ trend, especially at high TOC contents. This leads to the second point; a "normal marine" $\mathrm{C}$ to $\mathrm{S}$ trend for rocks containing $15 \mathrm{wt} \% \mathrm{C}$ would require a pyrite $\mathrm{S}$ content of $5 \mathrm{wt} \%$ and a reactive Fe content of nearly $4.4 \mathrm{wt} \%$. In a survey of reactive contents in continental margin sediments $(n=70)$, Raiswell \& Canfield (1998) measured an average reactive Fe content of $0.82 \pm 0.31 \mathrm{wt} \%$ with a maximum reactive concentration of $1.7 \mathrm{wt} \%$. Therefore, unit 3 of Xiamaling Formation, and modern marine sediments in general, contain insufficient reactive $\mathrm{Fe}$ to generate "normal marine" $\mathrm{C}$ to $\mathrm{S}$ trends at high TOC contents. For these reasons, comparing $\mathrm{C}$ to $\mathrm{S}$ trends in unit 3 of the Xiamaling Formation to "normal marine" $\mathrm{C}$ to $\mathrm{S}$ trends is uninformative in addressing $\mathrm{S}$ limitation in pyrite formation.

The presence of unsulfidized reactive iron in sediments (Fepy/FeHR < 0.7), however, indicates sulfur limiation in pyrite formation, and unsuldized reactive iron is found in unit 3 rocks (Diamond et al., 2018; Wang et al., 2017) (Figure 5). We therefore evaluate whether the presence of unsulfidized reactive iron in sediments is a necessary indication of severe sulfate limitation during 
pyrite formation. We note that it is not unusual for modern marine continental margin sediments to accumulate with unsulfidized reactive Fe (Raiswell \& Canfield, 1998 ; Canfield, 1989 ; Canfield et al., 1992 ; Aller et al., 1986). Thus, the presence of unsulfidized iron, by itself, does not speak to the availability of sulfate to form pyrite. Instead, the presence of unsulfidized iron indicates insufficient sulfide production by sulfate reduction to react with the reactive iron, where, in addition to sulfate availability, sulfate reduction rates can also be limited by the availability of reactive organic carbon. But, with this being the case, it might be considered unusual for unit 3 to have preserved unsulfidized reactive Fe in the presence of such high concentrations of TOC if sulfate did not limit pyrite formation.

To explore whether carbon or sulfur might have limited pyrite formation in unit 3, we look to comparisons with modern OMZ environments, as previous models have suggested that unit 3 deposited in the oxygenated waters below an ancient OMZ (Wang et al., 2017 ; Zhang et al., 2016). To do so, we again explore $\mathrm{C}$ to $\mathrm{S}$ relationships, but focused on comparisons to a specific geochemical environment. Thus, core-average trends in $\mathrm{C}$ vs $\mathrm{S}$ for the Peruvian margin $\mathrm{OMZ}$ are shown in Figure 7B (Boning et al., 2004) distinguishing between sediments deposited in various water-depth intervals. Overall, these data show that less pyrite forms in deeper waters, compared to shallower waters, despite similar, and indeed quite high, concentrations of organic carbon. Furthermore, the sediments found at water depths greater than $600 \mathrm{~m}$ deposited in oxygenated waters below the anoxic core of the Peruvian OMZ, and the trends in $\mathrm{C}$ to $\mathrm{S}$ from these sediments, in particular, resemble those from unit 3 of the Xiamaling Formation (Figures 6 and 7A). Thus, trends in $\mathrm{C}$ to $\mathrm{S}$ for Xiamaling Formation unit 3 are consistent with these sediments having deposited in oxygenated waters below an ancient OMZ, as previously suggested.

The data from Peruvian margin (Figure 7B) represent concentrations averaged over the upper 30 to $50 \mathrm{~cm}$ of sediment. One could imagine that pyrite formation might continue below these depths adding to the pyrite sulfur pool, thus influencing the carbon to sulfur systematics. In the Peruvian margin below $600 \mathrm{~m}$ water depth, of the sulfate gradient into the sediment is minimal, so any added sulfur would need to accompany a direct reduction of pore water sulfate to sulfide, without added sulfate supplied by diffusion. The porosity was not given for these sediments, but from our experience, 0.8 is a typical continental margin value. Thus, with a porosity of 0.8 and assuming a particle density of $2.5 \mathrm{~g} / \mathrm{cm}^{3}$, the complete reduction of $28 \mathrm{mM}$ sulfate will add only $0.14 \mathrm{wt} \% \mathrm{~S}$ to the sediments (see also Berner, 1964). This small amount of sulfur would not significantly affect the $\mathrm{C}$ to $\mathrm{S}$ trends in Figure 7B or the conclusion that Xiamaling Formation unit 3 resembles sediments 
deposited in oxygenated waters below an OMZ. Finally, we note that even in the anoxic core of the Peruvian margin $\mathrm{OMZ}$, the relationship between $\mathrm{C}$ to $\mathrm{S}$ does not reach the "modern marine" $\mathrm{C} / \mathrm{S}$ of 3/1, presumably due to a lack of sufficient reactive Fe in these TOC-rich sediments, for reasons as discussed above.

In deep-water sediments of the Peruvian margin, and despite significant amounts of organic matter and full seawater sulfate concentrations, sulfate production rates are suppressed (Boning et al., 2004) compared to rates found in sediments of similar TOC content deposited in shallower water (Figure 7C). Low rates of sulfate reduction were also measured in deep-water sediments of the Arabian Sea OMZ (Law et al., 2009). A plausible explanation for the low S contents (contributing to the high $\mathrm{C} / \mathrm{S}$ ratios) in deeper $\mathrm{OMZ}$ sediments is that organic matter reactivity decreases as it decomposes while settling through the water column (Jørgensen, 1982 ; Marsay et al., 2015)(Westrich \& Berner, 1984). Therefore, the organic matter that settles into deeper sediments is less reactive, and can support less sulfate reduction, than organic matter depositing into shallower sediments. Added to this would be additional mineralization as organic is decomposition by oxygen as well as electron acceptors other than sulfate (oxygen, nitrate, Mn and Fe oxides) in sediments depositing in oxygenated waters (Law et al., 2009).

As noted above, in previous models the sediments in unit 3 deposited in oxic waters below an ancient OMZ, and from sedimentological grounds, these sediments deposited well below storm wave base (Wang et al., 2017 ; Zhang et al., 2016). Therefore, a deep marine environment is indicated, and by analogy with modern OMZs, limited sedimentary sulfate reduction was likely. Thus, an OMZ setting for unit 3 of the Xiamaling Formation is perfectly consistent with modern marine analog environments. This does not imply, however, that the Xiamaling Formation unit 3 deposited in 600 meters of water as those below the anoxic core of the modern Peruvian OMZ. As discussed in Zhang et al. (2016), and elsewhere (Logan et al., 1995 ; Brocks et al., 2017), prokaryote ecosystems dominated Mesoproterozoic Era oceans, and prokaryotes, due to their small size, should sink more slowly than larger eukaryotes. This means that in Mesoproterozoic-Era oceans, organic matter exported from the surface ocean would have decomposed more intensely in the upper ocean having the effect of concentrating oxygen depletion in the upper regions of the oceans, allowing deep water to accumulate oxygen again at shallower depths than today (e.g., Meyer et al., 2016). Therefore, the same geochemical environment found at $600 \mathrm{~m}$ in modern OMZs could easily have been found in shallower waters for OMZs of the Mesoproterozoic Era. 
In the Xiahuayuan region, the transition from unit 3 to unit 2 marks a transition to anoxic bottom water conditions, and to dominantly ferruginous water chemistry (Wang et al., 2017). Ratios of C to $\mathrm{S}$ are variable, but generally lower than in unit 3, and some samples approach or exceed the "normal marine" line (Figure 7A). Under ferruginous conditions, which were common during the Mesoproterozoic and Neoproterozoic Eras (Planavsky et al., 2011 ; Canfield et al., 2008 ; Poulton \& Canfield, 2011 ; Sperling et al., 2015), pyrite formation is, by definition, limited by sulfide availability, but clearly more sulfide formed in unit 2 rocks per unit TOC than in underlying unit 3. Greater amounts of sulfide production could have resulted from a number of factors. A marine regression is one possible factor, as shallower waters would have intercepted more organic matter of a higher reactivity allowing higher rates of sediment sulfate reduction. Another factor could have been the expansion of basin anoxia to the sediment surface, and thus the loss of OMZ conditions. This would have inhibited oxic respiration below the OMZ, thus providing more organic matter to fuel anaerobic metabolism, including sulfate reduction, in the sediment.

The $\mathrm{C}$ to $\mathrm{S}$ ratios in unit 1 are generally lower than those from "normal marine" sediments. The organic-rich sediments from unit 1 are heavily enriched in reactive $\mathrm{Fe}$, providing more iron for sulfidization, and many of them deposited under euxinic conditions (Wang et al., 2017 ; Zhang et al., 2017). Indeed, the trends between $\mathrm{C}$ and $\mathrm{S}$ in unit 1 are similar to those in modern euxinic settings that accumulate high proportions of reactive $\mathrm{Fe}$ and where pyrite formation is not sulfide limited (Raiswell \& Berner, 1985). There is no evidence for sulfur limitation on pyrite formation in the high-TOC rocks of this unit.

\section{Sulfur isotopes}

The ${ }^{34} \mathrm{~S}$-enriched sulfur isotope values in unit 3 in the Chicheng region have been proposed to indicate sulfate reduction under sulfate-limited conditions due to basin restriction (Figure 3) (Diamond et al., 2018). With this model, a tendency towards ${ }^{34}$ S-depleted values in the transition to unit 2 occurred as the basin opened to the global ocean providing higher fractionations under the ensuing elevated sulfate concentrations. The return to more ${ }^{34} \mathrm{~S}$-enriched values higher in unit 2 , then, resulted from a return to greater basin restriction.

We evaluate this model by noting, first, that the trend towards ${ }^{34} \mathrm{~S}$-depleted sulfide isotopic values as seen at the transition from unit 3 to 2 at Chicheng is not obvious in the data from the Xiahuayuan region (Figure 3). Indeed, if anything, an opposite trend is observed when comparing the two regions. Therefore, these isotope shifts seem to reflect local rather than basin-wide processes. We 
also note that in the region of Xiahuayuan (Wang et al., 2017) (Figure 3), the bottom of unit 2 houses generally more ${ }^{34} \mathrm{~S}$-enriched sulfides than unit 3 (Wang et al., 2017), yet this unit has elevated trace metal contents and lower C/S ratios than unit 3 (Figures 4 and 7A). These results are incompatible with the basin restriction model of Diamond et al. (2018), where less basin restriction, yielding higher trace metal abundance and lower $\mathrm{C} / \mathrm{S}$ ratios should produce more ${ }^{34} \mathrm{~S}$-depleted sulfides. This is also true for upper unit 2 where we see the greatest trace metal enrichments, low $\mathrm{C} / \mathrm{S}$ values, yet $\delta^{34} \mathrm{~S}$ values similar to unit 3 (Figures 3, 4 and 7A), again incompatible with the basin restriction model of Diamond et al. (2018).

In addition, we note that the upper half of unit 1 is characterized by widely variable $\delta^{34} S$ values (Figure 3), where the ${ }^{34}$ S-enriched values are associated with trace metal-poor, TOC-poor greengray shales, and the ${ }^{34} \mathrm{~S}$-depleted values are associated with TOC-rich, trace metal-rich black shales (Wang et al., 2017). It seems unlikely that these fluctuations in $\delta^{34} \mathrm{~S}$ were associated with frequent opening and closing of the Xiamaling basin to the global ocean. Instead, these $\delta^{34} \mathrm{~S}$ variations have been explained by bottom-water fluctuating between oxic and anoxic conditions as possibly driven by climate change and subsequent changes in basin circulation (Zhang et al., 2017 ; Wang et al., 2017 ; Zhang et al., 2016 ; Zhang et al., 2015b). The ${ }^{34}$ S- enriched pyrites were formed in the water column of euxinic waters, where sulfate reduction was incomplete allowing pyrites to capture the isotope fractionation associated with sulfate reduction (Wang et al., 2017). In contrast, in the oxygenated waters, complete sulfate reduction in the sediments limited the expression of isotope fractionation (Wang et al., 2017).

In unit 1 , as elsewhere in the Xiamaling Formation (indeed in all sediments), $\delta^{34} \mathrm{~S}$ values are controlled by a balance of processes. These processes range from biologically imparted fractionations during sulfur metabolism to the processes controlling how these fractionations are preserved in the rock record including, critically, where in the water column (if anoxic) or sediment pyrite is formed relative to the extent of sulfate depletion (and thus the isotopic composition of the sulfide forming pyrite) (Canfield, 2001). None of these processes are constant in time leading to typical variations in sediment $\delta^{34} \mathrm{~S}$ (Canfield, 2001). Therefore, variations in the $\delta^{34} \mathrm{~S}$ of pyrite in a sedimentary sequence are normal, and changes in the concentration of sulfate is only one of numerous factors that can influence the preserved sulfur isotope record.

Overall, ${ }^{34} \mathrm{~S}$-enriched sulfur isotope values are common in sedimentary rocks from the Mesoproterozoic Era (e,g. Cox et al., 2016 ; Canfield \& Farquhar, 2009 ; Johnston et al., 2008 ; 
Wang et al., 2017 ; Sperling et al., 2014) and the Neoproterozoic Era (e.g. Canfield \& Farquhar, 2009 ; Fike et al., 2006 ; Canfield et al., 2007 ; Wu et al., 2015; Shen et al., 2010 ; McFadden et al., 2008) with $\delta^{34} \mathrm{~S}$ values ranging to over $10 \%$, similar to those observed in the Xiamaling Formation. These generally ${ }^{34} \mathrm{~S}$-enriched sulfides likely formed from seawater whose sulfate concentrations were much lower than today, likely by a factor of 10 or more (Shen et al., 2002 ; Canfield \& Farquhar, 2009; Kah et al., 2004). Thus, during Mesoproterozoic and Neoproterozoic times, sulfate was necessarily more limiting than today. Most sequences from these times also show variable $\delta^{34} \mathrm{~S}$, but it seems likely, at least in most cases, that processes other than varying degrees of basin restriction controlled this variability.

Finally, we make here numerous comparisons to modern OMZ environments. In the Peruvian OMZ, sediments within the anoxic core have $\delta^{34} S$ pyrite values in the range of -30 to $-35 \%$, while those depositing in oxic waters below the OMZ have $\delta^{34} \mathrm{~S}$ values of -40 to $-50 \%$ (Boning et al., 2004). These values (especially those from below the OMZ) are much more ${ }^{34} \mathrm{~S}$-depleted than those found in the Xiamaling Formation unit 3, and indeed, almost everything else in the geologic record until the late Neoproterozoic Era (Canfield \& Farquhar, 2009). We attribute the difference in $\delta^{34} \mathrm{~S}$ between the Xiamaling Formation and modern OMZs to much higher sulfate concentrations in modern seawater, allowing a greater expression of isotope fractionation (Canfield \& Farquhar, 2009). Also important may be the influence of the oxidative sulfur cycle on sulfur isotope fractionation (Canfield \& Thamdrup, 1994), and the oxidative sulfur cycle does not have an obvious expression in major sulfur isotope fractionation until the late Neoproterozoic Era (Canfield \& Teske, 1996). Therefore, for the $\delta^{34} \mathrm{~S}$ of pyrites, modern OMZs are a poor analogue to OMZs from the Mesoproterozoic Era.

\section{Mo concentration and Mo isotopes}

A key argument supporting restriction of the Xiamaling basin (Diamond et al., 2018) is that sedimentary rocks of unit 3 are trace-metal poor despite their high TOC concentrations (Figure 3) (Diamond et al., 2018: Wang et al., 2017 ; Zhang et al., 2016 ; Zhang et al., 2015b). In this view, and focusing on molybdenum (Mo), restricted circulation with the open ocean limited the supply of Mo to the basin, thus allowing basin water concentrations to be reduced to very low values, effectively eliminating the possibility of generating Mo enrichments in sediments depositing the anoxic waters of the basin. This lack of significant trace metal enrichment in unit 3 is obvious when 
comparing trends between TOC and Mo concentration in all units of the Xiamaling Formation (Figure 8A).

Thus, such Mo enrichments are incompatible with deposition in TOC-rich sediments of anoxic marine setting, but fully compatible with deposition in oxygenated waters below an OMZ as noted previously (Wang et al., 2017 ; Zhang et al., 2016). Indeed, trends in Mo vs TOC for the sediments depositing below the anoxic core of the modern Peruvian OMZ (Figure 8B) mimic the results of unit 3 of the Xiamaling Formation (Figure 8A). Thus, it appears that the trace metal geochemistry of Xiamaling Formation unit 3 is compatible with deposition in the oxygenated waters below an OMZ. Basin restriction is not required to explain these results.

Diamond et al. (2018) reported the first Mo isotope data for the Xiamaling Formation, and this data is compared with our new results in Figure 4 (see Table S1 for data) there. Where they overlap stratigraphically, the data between the two studies is quite compatible, and focusing on units 3 , $\delta^{98}$ Mo values range to high values of between $1.5 \%$ and $1.8 \%$. Overall, the relationship between molybdenum concentration and $\delta^{98}$ Mo for the Xiamaling Formation unit 3 (not including the top 5 $\mathrm{m}$ transition zone into two unit 2; Diamond et al., 2018) resembles closely the relationship found in oxic sediments deposited below the Peruvian OMZ (Figure 9). Also, the relationship between Mo concentration $\delta^{98} \mathrm{Mo}$ for unit 3 is quite different from the relationships seen for sediments depositing within the anoxic Peruvian OMZ core, and for MANOP (the manganese nodule program)-site sediments where Mo accumulates by adsorption onto Mn oxides (Figure 7).

The relationship between molybdenum concentration and isotopic composition for the Xiamaling Formation unit 3 also resembles that for sediments of the California Borderline Basins and the Mexican margin whose overlying water columns are oxygenated, but with low oxygen concentrations. Therefore, as with the other proxies discussed above, molybdenum isotope systematics for sediments of unit 3 are compatible with modern low-oxygen analogues, including sediments deposited in oxygenated waters below the anoxic core of modern OMZs.

Given standard interpretations of molybdenum isotope systematics in black shales, the highly enriched $\delta^{98} \mathrm{Mo}$ values of unit 3 and lower unit 2 (Figure 4) are consistent with extensive marine oxygenation (Kendall et al., 2017 ; Arnold et al., 2004 ; Dahl et al., 2011) as also discussed in Diamond et al. (2018). These values are, however, quite ${ }^{98}$ Mo-enriched compared to previous results from the Mesoproterozoic Era, where the similarly-aged Velkerri Formation has $\delta^{98}$ Mo 
values of up to $1 \%$ (Arnold et al., 2004). In the region of Xiahuayuan, all the highly ${ }^{98}$ Mo-enriched samples from unit 3 have low Mo concentrations of < 2 ppm (Figure 10). One would not normally expect sediments with the lowest Mo concentrations to best capture seawater isotopic compositions (e.g. Neubert et al., 2008). Therefore, we suggest that the elevated $\delta^{98}$ Mo values in unit 3 resulted from diagenetic remobilization and precipitation of ${ }^{98} \mathrm{Mo}$-enriched porewater Mo. The studies are few, but during Mo authigenesis in sediments, pore water Mo may become ${ }^{98}$ Mo-enriched compared to seawater (McManus et al., 2002). The mobilization during diffusion and precipitation of this ${ }^{98}$ Mo-enriched Mo in sediments with a low Mo concentration could generate $\delta^{98}$ Mo values elevated above those for seawater. We note that in unit 3, black shales alternate on a cm scale with chert-enriched samples, generating a potentially dynamic diagenetic environment. The mechanisms for precipitation in this model are not clear, but if this model is correct, then the maximum $\delta^{98} \mathrm{Mo}$ values for unit 3 for sediments from Xiahuayuan with elevated Mo concentrations would suggest seawater $\delta^{98}$ Mo values of about $1.1 \%$ (Figure 10).

Through most of unit $2, \delta^{98}$ Mo ranges between about 0 and $0.9 \%$ (Figures $4,10,11$ ). If the seawater $\delta^{98}$ Mo was around $1.1 \%$, then the more ${ }^{98}$ Mo-depleted values of unit 2 might suggest Mo sequestration in generally sulfide-limited environment (Neubert et al., 2008), despite indications for euxinic water column conditions at the top of the unit (Figure 5). Thus, even when the basin was "sulfidic", the sulfide concentrations may have been too low to promote full conversion of $\mathrm{MoO}_{4}{ }^{2-}$ to $\mathrm{MoS}_{4}{ }^{2-}$, and thus full expression of the seawater isotope value (Erickson \& Helz, 2000 ; Dahl et al., 2010 ; Neubert et al., 2008).

Into unit $1, \delta^{98}$ Mo becomes decidedly more ${ }^{98}$ Mo-enriched, with maximum values of around $1.1 \%$ (Figures 4 and 11). We also note that the most ${ }^{98}$ Mo-enriched values are found in rocks with $\mathrm{FeHR} / \mathrm{FeT}>0.4$ and FePy/FeHR $>0.7$, defining euxinic deposition (Figure 11). Therefore, it appears that unit 1 was ideally suited to preserve seawater $\delta^{98}$ Mo with a likely value of $1.1 \%$, as we also concluded for unit 3. A value of seawater $\delta^{98} \mathrm{Mo}$ of $1.1 \%$ is consistent with previous evaluations of seawater $\delta^{98}$ Mo at about this time (Arnold et al., 2004).

Unit 1 geochemistry seems to conform with traditional ideas that elevated sulfide concentrations are needed to preserve a seawater $\delta^{98} \mathrm{Mo}$ signal. This is not, however, true for unit 3 , where, from Fe speciation results, the geochemical environment was not euxinic, nor where the sediment pore waters overly sulfidic as judged by FePy/FeHR values of generally < 0.7 (Figure 5). We note, 
however, that in modern $\mathrm{OMZ}$ sediments, Mo becomes enriched in concentration before pore water sulfide accumulates, implying that processes other than interactions with sulfide (perhaps interactions with iron and manganese oxides) can deliver molybdenum into sediments (Scholz et al., 2017). We also note that sediment trap particles in oxygen-minimum zone settings can be well enriched in Mo concentration compared to the crustal average, and these enrichments are interpreted to result from association with organic matter (Nameroff, 2002), a process whose isotopic consequences have yet to be explored. Therefore, there is still much to be learned about molybdenum geochemistry and the processes controlling sediment $\delta^{98}$ Mo values. This bring us back to the results from the Chicheng region where values range up to $1.5 \%$, but these elevated values are not associated with particularly low Mo concentrations (Figure 4) (Diamond et al., 2018). It is unclear why these values are more ${ }^{98} \mathrm{Mo}$-enriched than our analysis would indicate for seawater $\delta^{98} \mathrm{Mo}$ at the time the Xiamaling Formation deposited. These values could represent basin heterogeneity in $\delta^{98}$ Mo or they could reflect similar types of isotope remobilization process that we suggest were active in unit 3 and lower unit 2 in the Xiahuayuan region.

\section{Iron Speciation and basin-wide chemistry}

The Fe speciation results from Chicheng show values of FeHR/FeT (Figure 5) decidedly below the “anoxic threshold" value of 0.38 (Raiswell \& Canfield, 2012 ; Raiswell \& Canfield, 1998) in unit 3 (Diamond et al., 2018). Such low values of FeHR/FeT would be consistent with deposition in oxygenated waters. Such an assessment, however, requires independent lines of geochemical evidence as low values of FeHR/FeT can also be potentially preserved, for example, in anoxic depositional settings experiencing high rates of sediment deposition or low fluxes of highly reactive iron to the sediment (Raiswell \& Canfield, 2012). We note that high-precision dating places the sediment deposition rate (after compaction and lithification) from upper unit 3 into lower unit 2 (Figure 2) at $6.7 \times 10^{-4} \mathrm{~cm} \mathrm{year}^{-1}$ (Zhang et al., 2017). This a very slow deposition rate and comparable to that found for sediments depositing in the deep Black Sea (Canfield, 1994). Therefore, it seems likely that the rate of sediment deposition was sufficiently slow to allow noticeable reactive iron enrichment if there was a reactive Fe flux. We also note, as discussed above, that the trace metal contents of unit 3 sediments at Chicheng are low (Figure 4), also consistent with oxic deposition. Such low trace metal contents are also unlikely to have resulted from particle dilution during rapid sediment deposition. Therefore, the iron speciation results, 
combined with trace metal results, would support deposition in oxygenated waters for unit 3 at Chicheng.

This model, however, is not favored by Diamond et al. (2018) who argue, instead, that unit 3 likely deposited in the anoxic waters of a restricted basin. Their assessment is based on the idea that highly restricted marine environments often contain anoxic bottom waters, and that the same basin restriction that caused extreme trace metal limitation (Figure 4 and above) also limited the supply of dissolved Fe from the open ocean and thus the flux of reactive Fe to the sediments. This view requires that the open ocean was the major source of reactive iron to the sediments of the Xiamaling Formation, and that local sediment sources of reactive iron from within the basin were insignificant. This view was supported by the observation that no obvious enrichment in reactive iron is observed in the sediments of the modern Salton Sea (de Koff et al., 2008). The Salton Sea, however, is a small (ca $35 \mathrm{~km}$ by $10 \mathrm{~km}$ ), shallow (16 meters maximum water depth) hypersaline enclosed basin with only seasonal water column anoxia and thus lacks a permanent chemocline (Holdren \& Montaño, 2002). As reactive iron enrichments in modern anoxic basins are typically sourced from Fe liberated from sediments at the chemocline (e.g. Canfield et al., 1996 ; Anderson \& Raiswell, 2004 ; Raiswell \& Canfield, 2012), the unstable chemocline of the Salton would not seem ideal for delivering Fe enrichments to the sediments.

Indeed, modern marine basins like the Black Sea, the Cariaco Basin and Framvaren Fjord each have stable chemoclines and show elevated reactive Fe delivery to the sediments (Raiswell \& Canfield, 1998), as well as the Landsort Deep of the Baltic Sea that shows a history of elevated reactive iron delivery associated with periods of water column anoxia (Hardisty et al., 2016). We do not imply that all anoxic basins will necessarily display characteristic reactive Fe enrichments. However, the Xiamaling Basin, with its large size and slow rate of sediment deposition, should have been an ideal environment from which to source reactive Fe sediments at the chemocline to accumulate in deep sediments of the basin.

Supporting this idea, reactive iron enrichments are found in the sediments of underlying unit 4 of the Xiamaling Formation, and unit 5 contains the largest known IF in the Mesoproterozoic Era. Reactive Fe enrichments are also found in units 2 and 1 (Figure 5). We cannot be certain that all of the reactive Fe in the Xiamaling Formation sediments originated from local sediment sources (the IF of unit 5 may have required an external Fe source; Canfield et al., 2018), but by analogy with modern anoxic basins with reactive Fe enrichments, much of it likely did. 
We also note that, in contrast the Chincheng region, unit 3 in the Xiahauyuan region does indeed record reactive Fe enrichments (Figure 5). The enrichments are not large or persistent, but they seem to directly contradict the suggestion of Diamond et al. (2018) that basin restriction cut off the source of reactive iron during unit 3 deposition. We note, furthermore, that the small reactive iron enrichments in unit 3 rocks at Xiahauyuan are compatible with observations from the modern Peru OMZ, where reactive Fe, liberated from the sediments of the anoxic core, can be transported to accumulate in the sediments of oxygenated waters below the OMZ core (Scholz et al., 2014).

Still, while there seems to have been a source for reactive Fe in the Xiamaling Basin during the deposition of unit 3, the complete lack of obvious reactive Fe enrichments at Chicheng is puzzling. One explanation would be that the whole water column at this site was oxygenated. This is compatible with the proxies, but perhaps difficult to reconcile with the high TOC content of the sediment, where one might expect a high oxygen demand as organic matter sank through the water column, generating oxygen depletion (an OMZ) in the water column somewhere above where the sediments deposited (Zhang et al., 2016).

Another possible explanation for low Fe enrichments at Chicheng deals with geochemistry of Fe in modern OMZ settings. While $\mathrm{Fe}^{2+}$ is mobilized from sediments of the anoxic OMZ core, with the nitrogenous conditions of modern OMZs, much of the $\mathrm{Fe}^{2+}$ is apparently oxidized anaerobically through microbial nitrate reduction, so much of the liberated $\mathrm{Fe}^{2+}$ is re-oxidized and re-deposited again in the anoxic OMZ waters (Scholz et al., 2016; Heller et al., 2017). This process of anaerobic $\mathrm{Fe}^{2+}$ oxidation limits $\mathrm{Fe}^{2+}$ transport through and ultimately out of the anoxic waters for accumulation in sediments of deeper oxygenated waters. We do not know to what extent nitrate persisted in ancient OMZ settings, but if it did, the process of anaerobic $\mathrm{Fe}^{2+}$ oxidation could limit the transport of reactive Fe from its sediment source. With this model, the Xiahuayuan region, closer to the sediment source, received an enhanced supply of $\mathrm{Fe}^{2+}$ compared to the Chicheng region to the northeast (Figure 1), thus explaining the limited accumulation of reactive $\mathrm{Fe}$ at Chicheng, despite an OMZ setting.

To summarize, there is evidence for enhanced reactive Fe accumulation in each of units 1-5 of the Xiamaling Formation, including unit 3. Therefore, it seems likely that when basin redox conditions permitted, reactive Fe could be supplied to anoxic basin waters for deposition in basin sediments. Therefore, the lack of iron enrichments in unit 3 at Chicheng likely had little to do with basin restriction, but rather the circumstances of water chemistry at the depositional site. The lack of Fe 
enrichments at Chicheng, coupled with a lack of trace metal accumulation (see above), are compatible with deposition in oxygenated waters, possibly below the anoxic core of an ancient $\mathrm{OMZ}$ as in the Xiahuayuan region. Therefore, the transition to euxinic conditions at Chicheng (and ferruginous conditions at Xiahuayuan) did not likely mark the opening of a restricted basin, but rather a change in water circulation and water chemistry in the Xiamaling Basin, possibly initiation by climate change as discussed elsewhere (Wang et al., 2017).

\section{Ratio of $\mathrm{Zr} / \mathrm{Ti}$}

The ratios of $\mathrm{Zr} / \mathrm{Ti}$ and $\mathrm{Zr} / \mathrm{Al}$ have been used to identify sediment source in the Xiamaling Formation (Diamond et al., 2018; Zhang et al., 2015b) and the Zr/Ti results from Chicheng (Diamond et al., 2018) are compared to those from Xiahuayuan (data from Zhang et al., 2015b) in Figure 12. The trends are almost identical (the absolute $\mathrm{Zr} / \mathrm{Ti}$ ratios from Chicheng are considerably higher owing to much higher $\mathrm{Zr}$ concentrations in the data of Diamond et al., 2018), indicating that the sediment source in this interval was remarkably consistent over a broad area of the basin. In the model of Diamond et al. (2018), changes in the ratio in $\mathrm{Zr} / \mathrm{Ti}$ in the transitions from unit 3 to unit 2 reflected changes in sediment source linked to opening of the highly restricted Xiamaling Basin to the ocean. This conclusion implies that in the transit from unit 3 to unit 2, the open ocean became a major source of particles to the Xiamaling Basin. This implication is impossible to verify, but we believe that a more likely source of sediment to the Xiamaling Basin was local rivers and atmospheric deposition (Zhang et al., 2015b).

The transition from unit 3 to unit 2 is also marked by important sedimentological changes. Most importantly, in the Xiahuayuan region, the characteristic alternating black shale/cherts of unit 3 give way to more or less continuous black shale in unit 2 (Zhang et al., 2015b ; Wang et al., 2017). In a previous study, Zhang et al. (2015b) linked these changes in both sedimentology and elemental ratios to changing climate as forced by the location of the Xiamaling Basin relative to the Intertropical Convergence Zone (ITCZ) and ancient Hadley Cell circulation. In this model, unit 3 was deposited in the downwelling limb of the ancient Hadley Cell, with black shale/chert alternations controlled by possible Milankovich-control of alternations on the exact location of the downwelling limb. In contrast, the transition from unit 3 to unit 2 resulted for large changes in Hadley Cell location such that Xiamaling Formation became placed under the more stable middle of the Hadley Cell. In the model of Zhang et al. (2015b), each of these changes in Hadley Cell location imparted changes in both wind and rain patterns, driving changes in particle source and the 
associated elemental ratios of particles depositing in the sediments. This model accounts for changes in both sedimentology as well as particle source in the transition from unit 3 to 2 in the Xiamaling Basin.

\section{Conclusions}

The Xiamaling Formation is a unique, and exceptionally well-preserved, geochemical repository providing fundamental insights into climate, ecosystem structure, atmospheric composition and marine geochemistry. A recent report has argued for severe restriction of the connection between the Xiamaling Basin and the open ocean, compromising interpretation of the geochemical records. This conclusion is based on the analysis of a variety of geochemical proxies as related to units 2 and 3 in the Xiamaling Formation in the region of Chicheng, with a special focus on the transition between the two units. The proxies explored were $\mathrm{C} / \mathrm{S}$ ratios, Mo abundance and isotopic compositions, Fe speciation, sulfur isotopes and $\mathrm{Zr} / \mathrm{Ti}$ ratios. We evaluated each of these proxies through comparisons between the geochemical results from the Chicheng region with the extensive data from the Xiahuayaun region, and through comparisons with modern analog environments. Through our analysis, we explored underlying assumptions in using these proxies as paleoenvironmental indicators with the hope of generating broader understanding of how these proxies can be used in paleoenvironmental reconstructions.

With regards to Xiamaling Formation, we conclude that severe basin restriction was not likely, and that the Xiamaling Formation more plausibly experienced active exchange with the sea through its depositional history. We also analyzed a new $\delta^{98}$ Mo data set from the Xiamaling Formation. We show that the $\delta^{98} \mathrm{Mo}$ was likely $1.1 \%$ during the time of the deposition of the Xiamaling Formation. Our data also revealed different pathways of Mo accumulation into sediments, each with the potential to reveal seawater $\delta^{98}$ Mo values. One pathway is well known and relies on the interactions between dissolved Mo and relatively elevated concentrations of sulfide. The other pathway does not apparently rely on sulfide and may involve the shuttling of Mo by either Fe and Mn oxides in OMZ environments or the association of Mo with organic matter.

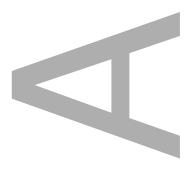

Figure Captions 
Figure 1. A) General stratigraphic column of the North China Craton. B) General geology of the North China Craton focusing on the Xiamaling Formation and its outcrops. Figure modified from Wang et al. (2017). References for chronology: a) Li et al. (2009), b) Liu et al. (2011), c) Zhang et al. (2015b), d) Zhang et al. (2012), e) Su et al. (2010), f) Li et al. (2014), g) Zhang et al. (2009a) i) Li et al. (2010), k) Lu \& Li (1991), 1) Gao et al. (2008), m) Zhang et al. (2013), n) Sun et al. (2013), o) Duan et al. (2014), p) Li et al. (2011), q) He et al. (2011)

Figure 2. The stratigraphy of the Xiamaling Formation. Modified from Wang et al (2017).

Figure 3. TOC concentrations, sulfur concentrations and the $\delta^{34} \mathrm{~S}$ of sulfide for the Xiamaling Formation from Xiahuayuan (panels on the left; open symbols outcrop, closed symbols core) and Chicheng (panels on the right). For the $\delta^{34} \mathrm{~S}$ from Xiahuayuan, samples with low TOC $(<1 \mathrm{wt} \%)$ are indicated separately from those with high TOC in the upper 45 meters where low TOC green shales alternate frequently with high TOC black shale. Data from: Diamond et al. (2018), Wang et al. (2017), Zhang et al. (2017), Zhang et al. (2016), Zhang et al. (2015b).

Figure 4. TOC concentrations, $\mathrm{Mo} / \mathrm{Al}$ and $\delta^{98} \mathrm{Mo}$ for the Xiamaling Formation from Xiahuayuan (panels on the left; open symbols outcrop, closed symbols core) and Chicheng (panels on the right). Data from: Diamond et al. (2018), Wang et al. (2017), Zhang et al. (2017), Zhang et al. (2016), Zhang et al. (2015b) including new data for $\delta^{98}$ Mo from the present study.

Figure 5. TOC concentrations, Fe/Al and Fe speciation for the Xiamaling Formation from Xiahuayuan (panels on the left; open symbols outcrop, closed symbols core) and Chicheng (panels on the right). Data from: Diamond et al. (2018), Wang et al. (2017), Zhang et al. (2017), Zhang et al. (2016), Zhang et al. (2015b).

Figure 6. TOC vs both S and "potential S" (open symbols) for the unit 3 of the Xiamaling Formation. "potential $S$ " is determined assuming all of the "reactive iron" is converted to pyrite. Brown symbols are for data from Xiahuayuan, while back symbols are for data from Chicheng. C/S lines of 3/1 (the normal marine line) and 10/1 are also included.

Figure 7. A) $\mathrm{C}$ to $\mathrm{S}$ relationship for units 1, 2 and 3 of the Xiamaling Formation, with data from Xiahuayuan. Comparable data for lower unit 2 and unit 3 can be found in Diamond et al. (2018). The "normal marine" C/S relationship of $3 / 1$ is also included. B) $\mathrm{C}$ to $\mathrm{S}$ relationship for various 
water depths for sediments of the oxygen minimum zone off the coast of Peru. Here, oxygenated bottom waters begin just above $600 \mathrm{~m}$ water depth. The "normal marine" $\mathrm{C} / \mathrm{S}$ relationship of $3 / 1$ is also included. Data from Boning et al. (2004). C) Sulfate reduction rates for various water depths for sediments of the oxygen minimum zone off the coast of Chile. Here, oxygenated bottom waters begin just above $600 \mathrm{~m}$ water depth. Data from Boning et al. (2004).

Figure 8. A) Organic carbon versus molybdenum enrichment (Mo/Al) for units 1, 2 and 3 of the Xiamaling Formation, with data from Xiahuayuan. B) Organic carbon versus molybdenum enrichment $(\mathrm{Mo} / \mathrm{Al})$ at various water depths for sediments of the Peruvian oxygen-minimum zone. Data from Boning et al. (2004).

Figure 9. Molybdenum concentration versus $\delta^{98}$ Mo values for sediments from the Xiamaling Formation (present study and from Diamond et al., 2018) compared to oxygen-minimum zone (OMZ) sediments of the coast of Peru (within the anoxic core and below the anoxic core) and for a variety of low oxygen (but still oxygenated) modern marine sediments from the California Borderland basins and the Mexican margin. Also included are manganese-rich deep-water sediments (MANOP sites) from the equatorial eastern Pacific Ocean. Modern sediment data comes from Poulson Brucker et al. (2009) and Scholz et al. (2017).

Figure 10. TOC concentrations, Mo concentrations and $\delta^{98}$ Mo for samples from lower unit 2, unit 3 and upper unit 4 of the Xiamaling Formation. Data for $\delta^{98}$ Mo for samples with under 2 ppm Mo are indicated with dark symbols.

Figure 11. Concentrations of TOC, Mo and S, as well as $\delta^{34} \mathrm{~S}$ and $\delta^{98}$ Mo for units 1 and 2 of the Xiamaling Formation from the Xiahuayuan region. Data from Wang et al. (2017) and present study.

Figure 12. Ratio of $\mathrm{Zr} / \mathrm{Ti}$ through the unit 3 to 2 transition compared between the Xiahuayuan region (graph on left) and Chicheng region (graph on right). Data from Zhang et al. (2015b) and Diamond et al. (2018).

\section{References}


Aller RC, Mackin JE, Cox RT, Jr. (1986) Diagenesis of Fe and S in Amazon inner shelf muds: apparent dominance of Fe reduction and implications for the genesis of ironstones. Continental Shelf Research, 6, 263-289.

Anbar AD, Knoll AH (2002) Proterozoic ocean chemistry and evolution: A bioinorganic bridge? Science, 297, 1137-1142.

Anderson TF, Raiswell R (2004) Sources and mechanisms for the enrichment of highly reactive iron in euxinic Black Sea sediments. American Journal of Science, 304, 203-233.

Arnold GL, Anbar AD, Barling J, Lyons TW (2004) Molybdenum isotope evidence for widespread anoxia in mid-Proterozoic oceans. Science, 304, 87-90.

Berkner LV, Marshall LC (1965) On the origin and rise of oxygen concentration in the Earth's atmosphere. Journal of the Atmospheric Sciences, 22, 225-261.

Berner RA (1964) Distribution and diagenesis of sulfur in some sediments from the Gulf of California. Marine Geology, 1, 117-140.

Berner RA, Raiswell R (1983) Burial of organic carbon and pyrite sulfur in sediment over Phanerozoic time: a new theory. Geochimica et Cosmochimica Acta, 47, 855-862. Boning P, Brumsack HJ, Bottcher ME, Schnetger B, Kriete C, Kallmeyer J, Borchers SL (2004) Geochemistry of Peruvian near-surface sediments. Geochimica Et Cosmochimica Acta, 68, 4429-4451.

Brocks JJ, Jarrett AJ, Sirantoine E, Hallmann C, Hoshino Y, Liyanage T (2017) The rise of algae in Cryogenian oceans and the emergence of animals. Nature, 548, 578.

Brocks JJ, Love GD, Summons RE, Knoll AH, Logan GA, Bowden SA (2005) Biomarker evidence for green and purple sulphur bacteria in a stratified Palaeoproterozoic sea. Nature, $437,866-$ 870 .

Canfield DE (1989) Reactive iron in marine sediments. Geochimica et Cosmochimica Acta, 53, 619632.

Canfield DE (1994) Factors influencing organic carbon preservation in marine sediments. Chemical Geology, 114, 315-329.

Canfield DE (2001) Biogeochemistry of sulfur isotopes. In: Reviews in Mineralogy and Geochemistry (eds Valley JW, Cole DR). Mineralogical Society of America, Blacksburg, VA, pp. 607-636.

This article is protected by copyright. All rights reserved 
Canfield DE (2014) Oxygen: A Four Billion Year History, Princeton University Press.

Canfield DE, Farquhar J (2009) Animal evolution, bioturbation, and the sulfate concentration of the oceans. Proceedings of the National Academy of Sciences of the United States of America, $106,8123-8127$.

Canfield DE, Lyons TW, Raiswell R (1996) A model for iron deposition to euxinic Black Sea sediments. American Journal of Science, 296, 818-834.

Canfield DE, Poulton SW, Knoll AH, Narbonne GM, Ross G, Goldberg T, Strauss H (2008)

Ferruginous conditions dominated later Neoproterozoic deep water chemistry. Science 321, 949-952.

Canfield DE, Poulton SW, Narbonne GM (2007) Late-Neoproterozoic deep-ocean oxygenation and the rise of animal life. Science, 315, 92-95.

Canfield DE, Raiswell R, Bottrell S (1992) The reactivity of sedimentary iron minarals toward sulfide. American Journal of Science, 292, 659-683.

Canfield DE, Teske A (1996) Late Proterozoic rise in atmospheric oxygen concentration inferred from phylogenetic and sulphur-isotope studies. Nature, 382, 127-132.

Canfield DE, Thamdrup B (1994) The production of ${ }^{34}$ S-depleted sulfide during bacterial disproportionation of elemental sulfur. Science, 266, 1973-1975.

Canfield DE, Zhang S, Wang H, Wang X, Zhao W, Su J, Bjerrum CJ, Haxen ER, Hammarlund EU (2018) A Mesoproterozoic iron formation. Proceedings of the National Academy of Sciences, 201720529.

Cohen PA, Macdonald FA (2015) The proterozoic record of eukaryotes. Paleobiology, 1-23.

Cox GM, Jarrett A, Edwards D, Crockford PW, Halverson GP, Collins AS, Poirier A, Li Z-X (2016)

Basin redox and primary productivity within the Mesoproterozoic Roper Seaway. Chemical Geology, 440, 101-114.

Dahl TW, Anbar AD, Gordon GW, Rosing MT, Frei R, Canfield DE (2010) The behavior of molybdenum and its isotopes across the chemocline and in the sediments of sulfidic Lake Cadagno, Switzerland. Geochimica Et Cosmochimica Acta, 74, 144-163.

Dahl TW, Canfield DE, M.T. R, Frei R, Gordon GW, Knoll AH, Anbar AD (2011) Molybdenum evidence for expansive sulfidic water masses in $~ 750$ Ma oceans. Earth and Planetary Science Letters.

This article is protected by copyright. All rights reserved 
De Koff JP, Anderson MA, Amrhein C (2008) Geochemistry of iron in the Salton Sea, California. Hydrobiologia, 604, 111-121.

Diamond C, Planavsky N, Wang C, Lyons T (2018) What the 1.4 Ga Xiamaling Formation can and cannot tell us about the mid-Proterozoic ocean. Geobiology.

Dohrmann M, Wörheide G (2017) Dating early animal evolution using phylogenomic data. Scientific reports, 7, 3599.

Duan C, Li YH, Wei MH, Yang Y, Hou KJ, Chen XD, Zou B (2014) U-Pd dating study of detrital zircons from the Chuanlinggou Formation in the Jiangjiazhai iron deposit, North China Craton and us geological significances. Acta Petrologica Sinica, 30, 35-48.

Dupont CL, Butcher A, Valas RE, Bourne PE, Caetano-Anollés G (2010) History of biological metal utilization inferred through phylogenomic analysis of protein structures. Proceedings of the National Academy of Sciences, 107, 10567-10572.

Erickson BE, Helz GR (2000) Molybdenum(VI) speciation in sulfidic waters: Stability and lability of thiomolybdates. Geochimica Et Cosmochimica Acta, 64, 1149-1158.

Erwin DH, Laflamme M, Tweedt SM, Sperling EA, Pisani D, Peterson KJ (2011) The Cambrian Conundrum: Early Divergence and Later Ecological Success in the Early History of Animals. Science, 334, 1091-1097.

Fan W (2015) Geological features and research progress of the Mesoroterozoic Xiamaling Formation in the North China craton: a review after nearly 100 years of study. Geological Review, 61, 1383-1406.

Fike DA, Grotzinger JP, Pratt LM, Summons RE (2006) Oxidation of the Ediacaran Ocean. Nature, 444, 744-747.

Gao LZ, Zhang CH, Shi XY, Song B, Wang ZQ, Liu YM (2008) Mesoproterozoic age for xiamaling formation in north china plate indicated by zircon SHRIMP dating. Chinese Science Bulletin, 53, 2665-2671.

Hardisty DS, Riedinger N, Planavsky NJ, Asael D, Andrén T, Jørgensen BB, Lyons TW (2016) A Holocene history of dynamic water column redox conditions in the Landsort Deep, Baltic Sea. American Journal of Science, 316, 713-745. 
He ZJ, Niu BG, Zhang XY, Zhao LP, Liu RY (2011) Discovery of the paleo-weathered mantle of the rapakivi granite covered by the Proterozoic Changzhougou Formation in the Miyun area, Beijing and their detrital zircon dating. Geological Bulletin of China, 30, 798-802.

Heller MI, Lam PJ, Moffett JW, Till CP, Lee J-M, Toner BM, Marcus MA (2017) Accumulation of Fe oxyhydroxides in the Peruvian oxygen deficient zone implies non-oxygen dependent Fe oxidation. Geochimica et Cosmochimica Acta, 211, 174-193.

Holdren GC, Montaño A (2002) Chemical and physical characteristics of the Salton Sea, California. Hydrobiologia, 473, 1-21.

Hu J, Li Z, Gong W, Hu G, Dong X (2016) Meso-Neoproterozoic Stratigraphic and Tectonic Framework of the North China Craton. In: Main Tectonic Events and Metallogeny of the North China Craton. Springer, pp. 393-422.

Johnston DT, Farquhar J, Summons RE, Shen Y, Kaufman AJ, Masterson AL, Canfield DE (2008)

Sulfur isotope biogeochemistry of the Proterozoic McArthur Basin. Geochimica et Cosmochimica Acta, 72, 4278-4290.

Jørgensen BB (1982) Mineralization of organic matter in the sea bed - the role of sulfate reduction. Nature, 296, 643-645.

Kah LC, Lyons TW, Frank TD (2004) Low marine sulphate and protracted oxygenation of the Proterozoic biosphere. Nature, 431, 834-838.

Kendall B, Dahl TW, Anbar AD (2017) The stable isotope geochemistry of molybdenum. Reviews in Mineralogy and Geochemistry, 82, 683-732.

Knoll AH (1992a) Biological and biogeochemical preludes to the Ediacaran radiation. In: Origin and Early Evolution of the Metazoa (eds Lipps JH, Signor PW). Plenum Press, New York, pp. 5384.

Knoll AH (1992b) The early evolution of eukaryotes: a geological perspective. Science, 256, 622627.

Knoll AH (2011) The multiple origins of complex multicellularity. annual review of Earth and Planetary 39, 217-239.

Knoll AH (2014) Paleobiological perspectives on early eukaryotic evolution. Cold Spring Harbor Perspectives in Biology, 1-14. 
Knoll AH, Carroll SB (1999) Early animal evolution: Emerging views from comparative biology and geology. Science, 184, 2129-2137.

Knoll AH, Hewitt D (2011) Phylogenetic, functional and geological perspectives on complex multicellularity. In: The major transitions in evolution revisited., (eds Calcott B, Sterelny K). MIT Press, Cambridge, MA, pp. 251-270.

Knoll AH, Javaux EJ, Hewitt D, Cohen P (2006) Eukaryotic organisms in Proterozoic oceans. Philosophical Transactions of the Royal Society B: Biological Sciences, 361, 1023-1038. Knoll AH, Nowak MA (2017) The timetable of evolution. Science advances, 3, e1603076. Law GTW, Shimmield TM, Shimmield GB, Cowie GL, Breuer ER, Harvey SM (2009) Manganese, iron, and sulphur cycling on the Pakistan margin. Deep-Sea Research Part li-Topical Studies in Oceanography, 56, 305-323.

Li H, Su WB, Zhou HY, Geng JZ, Xiang ZQ, Cui YR, Liu WC, Lu SN (2011) The base age of the Chengchengian System and in the northern North China Craton should be younger than $1670 \mathrm{Ma}$ : constraints from zircon U-Pb LA_MC_ICPMS dating of a granite porphyry dike in Miyun County, Beijing. Earth Science Frontiers, 18, 108-120.

Li HK, Lu SN, Li HM, Sun LX, Xiang ZQ, Geng JZ, Zhou HY (2009) Zircon and beddeleyite U-Pb dating of basic rock sills intruding Xiamaling Formation, North China. Geological Bulletin of China, 2009, 1396-1404.

Li HK, Su WB, Zhou HY, Xiang ZQ, Tian H, Yang LG, Huff WD, Ettensohn FR (2014) The first precise age constraints on the Jixian system of the Meso-to Neoproterozoic standard section of China: SHRIMP zircon U-Pb dating of bentonites from the Wumishan and Tieling formations in the Jixian Section, North China Craton. Acta Petrologica Sinica, 30, 2999-3012.

Li HK, Zhu SX, Xiang ZQ, Su WB, Lu SN, Zhou HY, Geng JZ, Li S, Yang FJ (2010) Zircon U-Pb dating on tuff bed from Gaoyuzhuang Formation in Yanqing, Beijing: Further constraints on the new subdivision of the Mesoproterozoic stratigraphy in the northern North China Craton. Acta Petrologica Sinica, 26, 2131-2140.

Liu Y, Zhong N, Tian Y, Qi W, Mu G (2011) The oldest oil accumulation in China: Meso-Proterozoic Xiamaling Formation bituminous sandstone reservoirs. Petroleum Exploration Development (in Chinese), 38, 503-512. 
Logan GA, Hayes JM, Hieshima GB, Summons RE (1995) Terminal Proterozoic reorganization of biogeochemical cycles. Nature, 376, 53-56.

Lu SN, Li HM (1991) A precise U-Pb zircon age determination for the volcanics of the Dahongyu Formation, Changcheng System in Jixian. Bulletin of Chinese Academy of Geological Sciences, 22, 137-146.

Lyons TW, Reinhard CT, Planavsky NJ (2014) The rise of oxygen in Earth's early ocean and atmosphere. Nature, 506, 307-315.

Marsay CM, Sanders RJ, Henson SA, Pabortsava K, Achterberg EP, Lampitt RS (2015) Attenuation of sinking particulate organic carbon flux through the mesopelagic ocean. Proceedings of the National Academy of Sciences of the United States of America, 112, 1089-1094.

Mcfadden KA, Huang J, Chu XL, Jiang GQ, Kaufman AJ, Zhou CM, Yuan XL, Xiao SH (2008) Pulsed oxidation and bioloical evolution in the Ediacaran Doushantuo Formation. Proceedings of the National Academy of Sciences of the United States of America, 105, 3197-3202.

Mcmanus J, Large Lakes Observatory UOM, Duluth, Minnesota, 55812, USA, Nägler TF, Universitåt Bern IFG, Bern, Erlachstrasse 9a, Ch-3012, Switzerland, Siebert C, Universitåt Bern IFG, Bern, Erlachstrasse 9a, Ch-3012, Switzerland, Wheat CG, Global Undersea Research Unit ML, California, P.O. Box 475, 95039, USA, Hammond DE (2002) Oceanic molybdenum isotope fractionation: Diagenesis and hydrothermal ridge-flank alteration. $G^{3}$, doi:10.1029/2002GC000356, 3.

Meng QR, Wei HH, Qu YQ, Ma SX (2011a) Stratigraphic and sedimentary records of the rift to drift evolution of the northern North China craton at the Paleo- to Mesoproterozoic transition. Gondwana Research, 20, 205-218.

Meng QR, Wei HH, Qu YQ, Ma SX (2011b) Stratigraphic and sedimentary records of the rift to drift evolution of the northern North China craton at the Paleo- to Mesoproterozoic transition. Gondwana Research, 20, 205-218.

Meyer K, Ridgwell A, Payne J (2016) The influence of the biological pump on ocean chemistry: implications for long-term trends in marine redox chemistry, the global carbon cycle, and marine animal ecosystems. Geobiology, 14, 207-219. 
Mills DB, Francis WR, Vargas S, Larsen M, Elmans CPH, Canfield DE, Woerheide G (2018) The last common ancestor of animals lacked the HIF pathway and respired in low-oxygen environments. eLIFE.

Mills DB, Ward LM, Jones C, Sweeten B, Forth M, Treusch AH, Canfield DE (2014) Oxygen requirements of the earliest animals. Proceedings of the National Academy of Sciences of the United States of America, 111, 4168-4172.

Nameroff TJ (2002) Suboxic trace metal geochemistry in the eastern tropical North Pacific. Geochimica Et Cosmochimica Acta, 66, 1139-1158.

Neubert N, Nagler TF, Bottcher ME (2008) Sulfidity controls molybdenum isotope fractionation into euxinic sediments: Evidence from the modern Black Sea. Geology, 36, 775-778.

Nursall JR (1959) Oxygen as a prerequisite to the origin of the metazoa. Nature, 183, 1170-1172. Nägler TF, Anbar AD, Archer C, Goldberg T, Gordon GW, Greber ND, Siebert C, Sohrin Y, Vance D (2014) Proposal for an international molybdenum isotope measurement standard and data representation. Geostandards and Geoanalytical Research, 38, 149-151.

Parfrey LW, Lahr DJ, Knoll AH, Katz LA (2011) Estimating the timing of early eukaryotic diversification with multigene molecular clocks. Proceedings of the National Academy of Sciences, 108, 13624-13629.

Planavsky NJ, Mcgoldrick P, Scott CT, Li C, Reinhard CT, Kelly AE, Chu X, Bekker A, Love GD, Lyons TW (2011) Widespread iron-rich conditions in the mid-Proterozoic ocean. Nature, 477, 448451.

Poulson Brucker RL, Mcmanus J, Severmann S, Berelson WM (2009) Molybdenum behavior during early diagenesis: Insights from Mo isotopes. Geochemistry, Geophysics, Geosystems, 10.

Poulson RL, Siebert C, Mcmanus J, Berelson WM (2006) Authigenic molybdenum isotope signatures in marine sediments. Geology, 34, 617-620.

Poulton SW, Canfield DE (2011) Ferruginous Conditions: A Dominant Feature of the Ocean through Earth's History. Elements, 7, 107-112.

Poulton SW, Krom MD, Raiswell R (2004) A revised scheme for the reactivity of iron (oxyhydr)oxide minerals towards dissolved sulfide. Geochimica et Cosmochimica Acta, 68, 3703-3715. 
Qiao S, Kawakubo Y, Cheng YJ, Nishiyama T, Fujii T, Furukawa K (2008) Anammox process for synthetic and practical wastewater treatment using a novel kind of biomass carriers. Water Science and Technology, 58, 1335-1341.

Qu Y, Pan J, Ma S, Lei Z, Li L, Wu G (2014) Geological characteristics and tectonic significance of unconformaities in Mesoproterozoic successions in the northern margin of the North China Block. Geoscience Frontiers, 5, 127-138.

Raiswell R, Berner RA (1985) Pyrite formation in euxinic and semi-euxinic sediments. American Journal of Science, 285, 710-724.

Raiswell R, Canfield DE (1998) Sources of iron for pyrite formation in marine sediments. American Journal of Science, 298, 219-245.

Raiswell R, Canfield DE (2012) The Iron Biogeochemical Cycle Past and Present Geochemical Perspectives, 1, 1-220.

Raiswell R, Canfield DE, Berner RA (1994) A comparison of iron extraction methods for the determination of degree of pyritisation and thee recognition of iron-limited pyrite formation. Chemical Geology, 111, 101-110.

Scholz F, Löscher CR, Fiskal A, Sommer S, Hensen C, Lomnitz U, Wuttig K, Göttlicher J, Kossel E, Steininger R (2016) Nitrate-dependent iron oxidation limits iron transport in anoxic ocean regions. Earth and Planetary Science Letters, 454, 272-281.

Scholz F, Severmann S, Mcmanus J, Hensen C (2014) Beyond the Black Sea paradigm: The sedimentary fingerprint of an open-marine iron shuttle. Geochimica Et Cosmochimica Acta, $127,368-380$.

Scholz F, Siebert C, Dale AW, Frank M (2017) Intense molybdenum accumulation in sediments underneath a nitrogenous water column and implications for the reconstruction of paleoredox conditions based on molybdenum isotopes. Geochimica et Cosmochimica Acta, 213, 400-417.

Scott C, Lyons TW, Bekker A, Shen Y, Poulton SW, Chu X, Anbar AD (2008) Tracing the stepwise oxygenation of the Proterozoic ocean. Nature, 452, 456-459.

Shen B, Xiao SH, Zhou CM, Kaufman AJ, Yuan XL (2010) Carbon and sulfur isotope chemostratigraphy of the Neoproterozoic Quanji Group of the Chaidam Basin, NW China: 
Basin stratification in the aftermath of an Ediacaran glaciation postdating the Shuram event? Precambrian Research, 177, 241-252.

Shen Y, Canfield DE, Knoll AH (2002) Middle Proterozoic ocean chemistry: Evidence from the McArthur Basin, Northern Australia. American Journal of Science, 302, 81-109.

Sperling EA, Rooney AD, Hays L, Sergeev VN, Vorob'eva NG, Sergeeva ND, Selby D, Johnston DT, Knoll AH (2014) Redox heterogeneity of subsurface waters in the Mesoproterozoic ocean. Geobiology, 12, 373-386.

Sperling EA, Wolock CJ, Morgan AE, Gill BC, Kunzmann M, Halverson GP, Macdonald FA, Knoll AH, Johnston DT (2015) Statistical analysis of iron geochemical data suggests limited late proterozoic oxygenation. Nature, 523, 451-454.

Su W, Li H, Huff W, Ettensohn F, Zhang S, Zhou H, Wan Y (2010) SHRIMP U-Pb dating for a Kbentonite bed in the Tieling Formation, North China. Chinese Science Bulletin, 55, 33123323.

Sun H, Gao LZ, Bao C, Chen Y, Liu D (2013) SHRIMP zircon U-Pb of Mesproterozoic Chuanlinggou Formation from Kuancheng County in Hebei Province and its geological implications. Acta Geologica Sinica- (in Chinese), 87, 591-596.

Tang D, Shi X, Jiang G, Wu T, Ma J, Zhou X (2018) Stratiform siderites from the Mesoproterozoic Xiamaling Formation in North China: Genesis and environmental implications. Gondwana Research, 58, 1-15.

Tang D, Shi X, Ma J, Jiang G, Zhou X, Shi Q (2017) Formation of shallow-water glaucony in weakly oxygenated Precambrian ocean: An example from the Mesoproterozoic Tieling Formation in North China. Precambrian Research, 294, 214-229.

Towe KM (1970) Oxygen-collagen priority and the early Metazoan fossil record. Proc. Nat. Acad. Sci., 65, 781-788.

Wang W, Liu S, Santosh M, Deng Z, Guo B, Zhao Y, Zhang S, Yang P, Bai X, Guo R (2015) Late Paleoproterozoic geodynamics of the North China Craton: geochemical and zircon $\mathrm{U}-\mathrm{Pb}-\mathrm{Hf}$ records from a volcanic suite in the Yanliao rift. Gondwana Research, 27, 300-325.

Wang X, Zhang S, Wang H, Bjerrum CJ, Hammarlund EU, Haxen ER, Su J, Wang Y, Canfield DE (2017) Oxygen, climate and the chemical evolution of a 1400 million year old tropical marine setting. American Journal of Science, 317, 860-899. 
Wen H, Carignan J, Cloquet C, Zhu X, Zhang Y (2010) Isotopic delta values of molybdenum standard reference and prepared solutions measured by MC-ICP-MS: Proposition for delta zero and secondary references. Journal of Analytical Atomic Spectrometry, 25, 716-721.

Wen H, Carignan J, Zhang Y, Fan H, Cloquet C, Liu S (2011) Molybdenum isotopic records across the Precambrian-Cambrian boundary. Geology, 39, 775-778.

Westrich JT, Berner RA (1984) The role of sedimentary organic matter in bacterial sulfat reduction: The G model tested. The American Society of Limnology and Oceanograhy, 29, 236-249.

Wu N, Farquhar J, Fike DA (2015) Ediacaran sulfur cycle: Insights from sulfur isotope measurements on paired sulfate-pyrite in the Huqf supergroup of Oman. Geochemica et Cosmochimica Acta, 164, 352-364.

Zhang J, Tian H, Li H, Su W, Zhou H, Xiang Z, Geng J, Yang L (2015a) Age, geochemistry and zircon $\mathrm{Hf}$ isotope of the alkaline basaltic rocks in the middle section of the Yan-Liao aulacogen along the northern margin of the North China Craton: New evidence for the breakup of the Columbia Supercontinent. Acta Petrologica Sinica, 31, 3129-3146.

Zhang K, Zhu X-K (2013a) Basic geological characteristics of the siderite-rich strata in the Xiamaling Formation, Jixian County. Acta Petrologica et Mineralogica (in Chinese), 32, 529-537.

Zhang K, Zhu X (2013b) Genesis of siderites in the Xiamaling Formation of Jiaxian Section and its paleoceanic significance. Acta Geologica Sinica- (in Chinese), 87.

Zhang K, Zhu X, Wood RA, Shi Y, Gao Z, Poulton SW (2018) Oxygenation of the Mesoproterozoic ocean and the evolution of complex eukaryotes. Nature Geoscience, 1.

Zhang S-H, Zhao Y (2016) Magmatic records of the late Paleoproterozoic to Neoproterozoic extensional and rifting events in the North China Craton: A preliminary review. In: Main Tectonic Events and Metallogeneny of the North China Craton (eds Zhai M, Zhaio Y, Zhaio T). Springer, Singapore, pp. 359-391.

Zhang S, Wang X, Hammarlund EU, Wang H, Costa MM, Bjerrum CJ, Connelly JN, Zhang B, Bian L, Canfield DE (2015b) Orbital forcing of climate 1.4 billion years ago. PNAS, 112, E1406E1413.

Zhang S, Wang X, Wang H, Hammarlund EU, Su J, Wang Y, Canfield DE (2017) The oxic degradation of sedimentary organic matter $1.4 \mathrm{Ga}$ constrains atmospheric oxygen levels Biogeosciences, 14, 2133-2149.

This article is protected by copyright. All rights reserved 
Zhang SC, Wang XM, Wang HJ, Bjerrum CJ, Hammarlund EU, Costa MM, Connelly JN, Zhang BM, Su J, Canfield DE (2016) Sufficient oxygen for animal respiration 1,400 million years ago. Proceedings of the National Academy of Sciences of the United States of America, 113, 1731-1736.

Zhang SH, Yue Z, HaO Y, Hu JM, Wu F (2013) New constraints on ages of the Chuanlinggou and Tuanshanzi formations of the Chengcheng System in the Yan-Liao area in the northern North China Craton. Acta Petrologica Sinica, 29, 2481-2490.

Zhang SH, Zhao Y, Santosh M (2012) Mid-Mesoproterozoic bimodal magmatic rocks in the northern North China Craton: Implications for magmatism related to breakup of the Columbia supercontinent. Precambrian Research, 222, 339-367.

Zhang SH, Zhao Y, Yang ZY, He ZF, Wu H (2009a) The 1.35 Ga diabase sills from the northern North China Craton: Implications for breakup of the Columbia (Nuna) supercontinent. Earth and Planetary Science Letters, 288, 588-600.

Zhang Y-X, Wen H-J, Fan H-F (2009b) Chemical pretreatment methods for measurement of Mo isotope ratio on geological samples. Chinese Journal of Analytical Chemistry, 37, 216-220.

Zhu S, Zhu M, Knoll AH, Yin Z, Zhao F, Sun S, Qu Y, Shi M, Liu H (2016) Decimetre-scale multicellular eukaryotes from the 1.56-billion-year-old Gaoyuzhuang Formation in North China. Nature Communications, 7.

Zhu X, Zhang K, Zhang F, Gao Z, Dong A, Bao C, Guo Y, Yan B, Liu H (2013) Discovery of siderite concretes in Mesoproterozoic Xiamaling Formation, Jixian section. Geological Reviews (in chinese), 59.

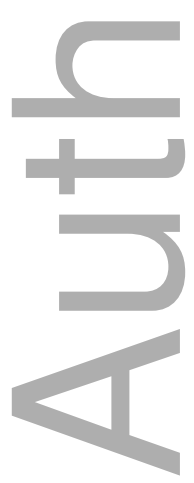

This article is protected by copyright. All rights reserved 


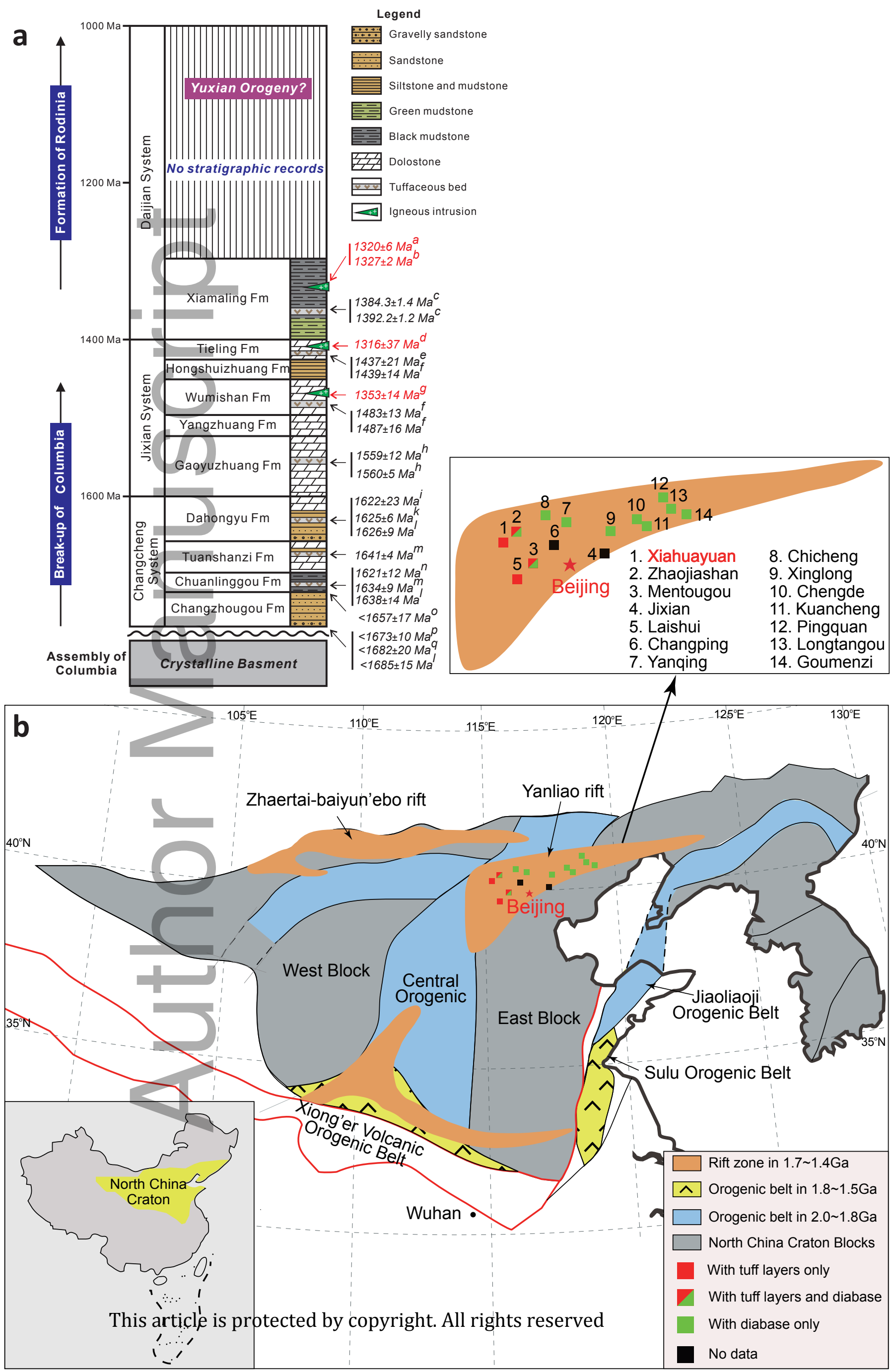




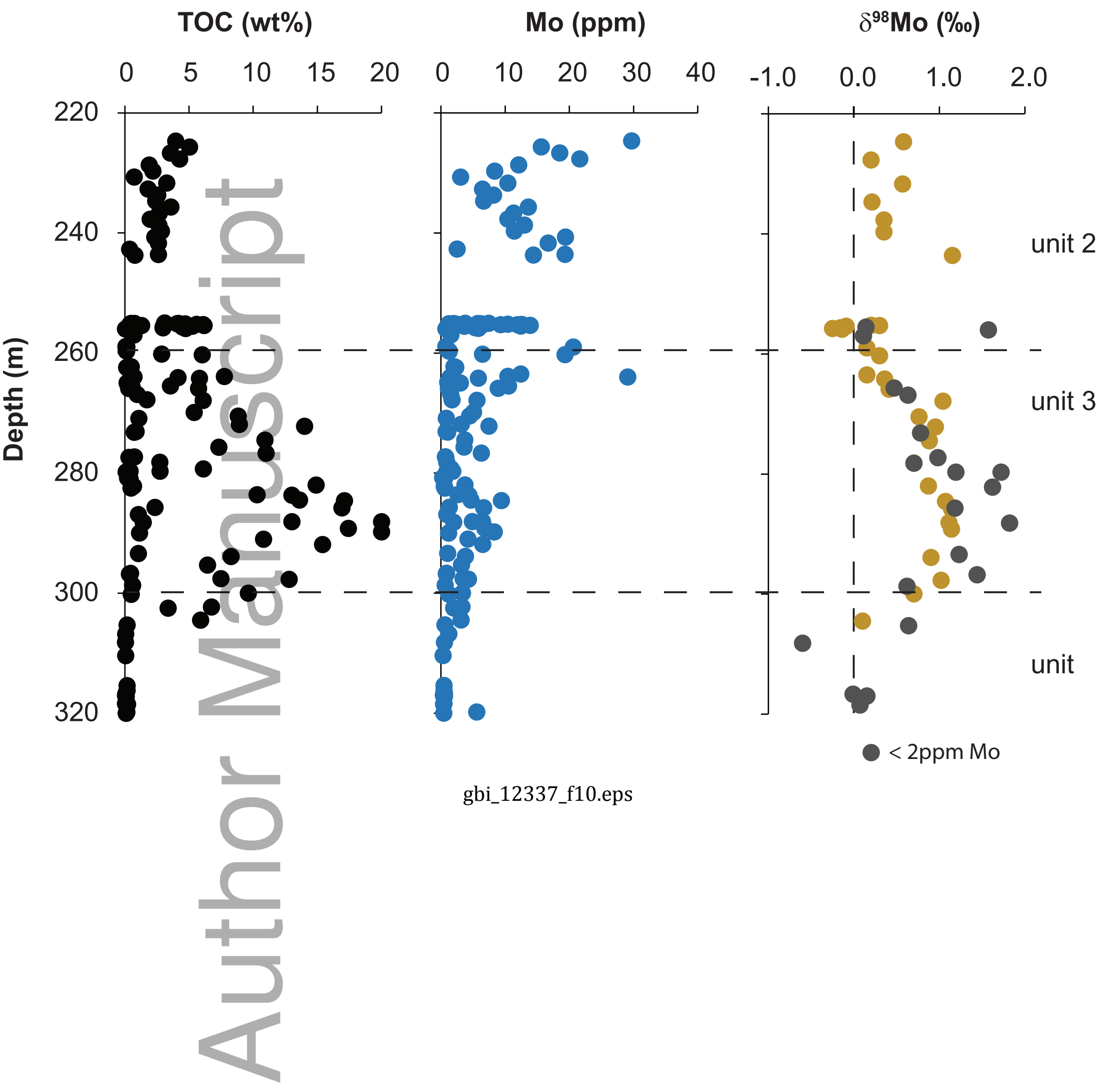

This article is protected by copyright. All rights reserved 
$\mathrm{Zr} / \mathrm{Ti}$ (ppm/wt\%)

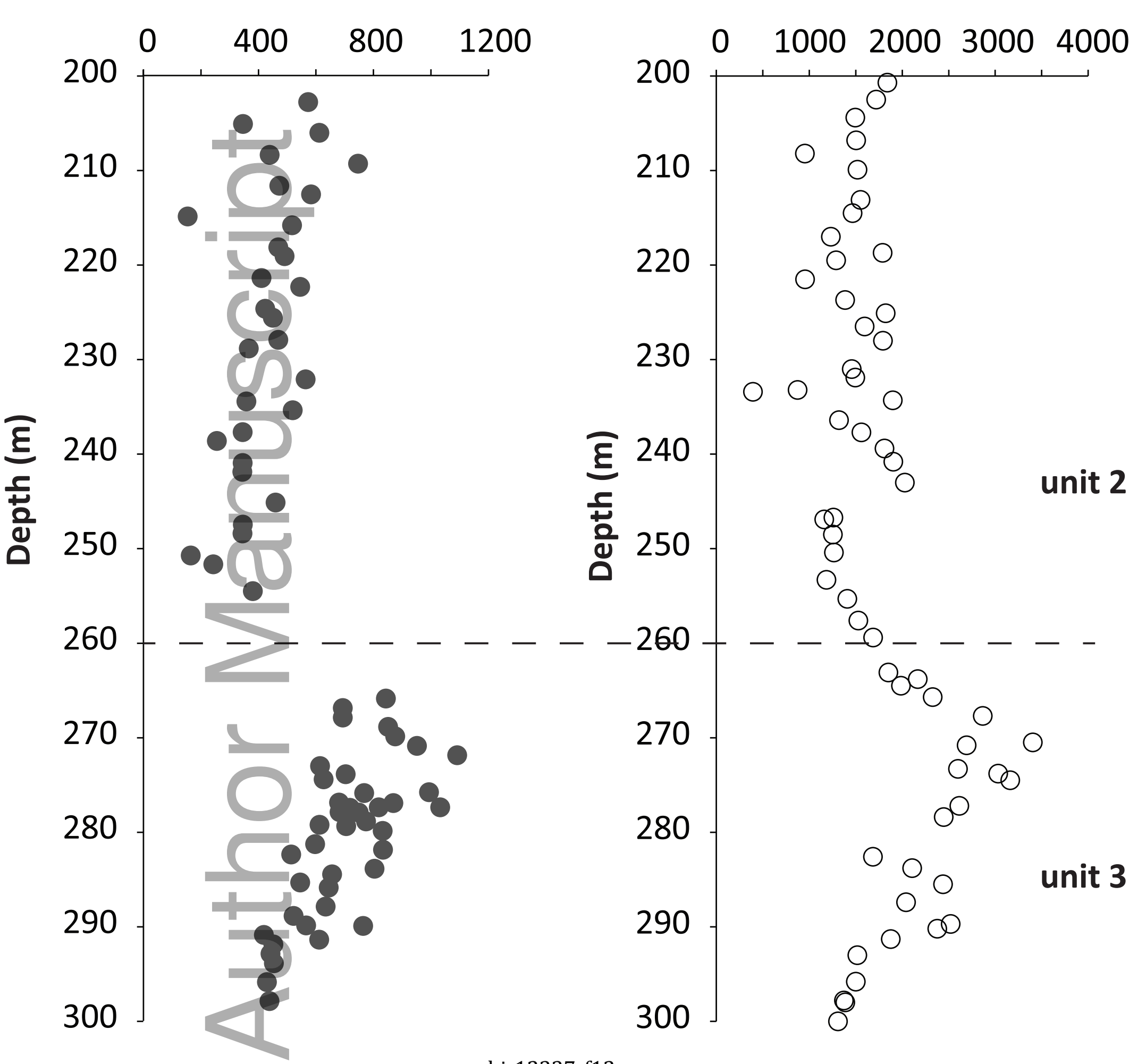

gbi_12337_f12.eps
$\mathrm{Zr} / \mathrm{Ti}$ (ppm/wt\%) 


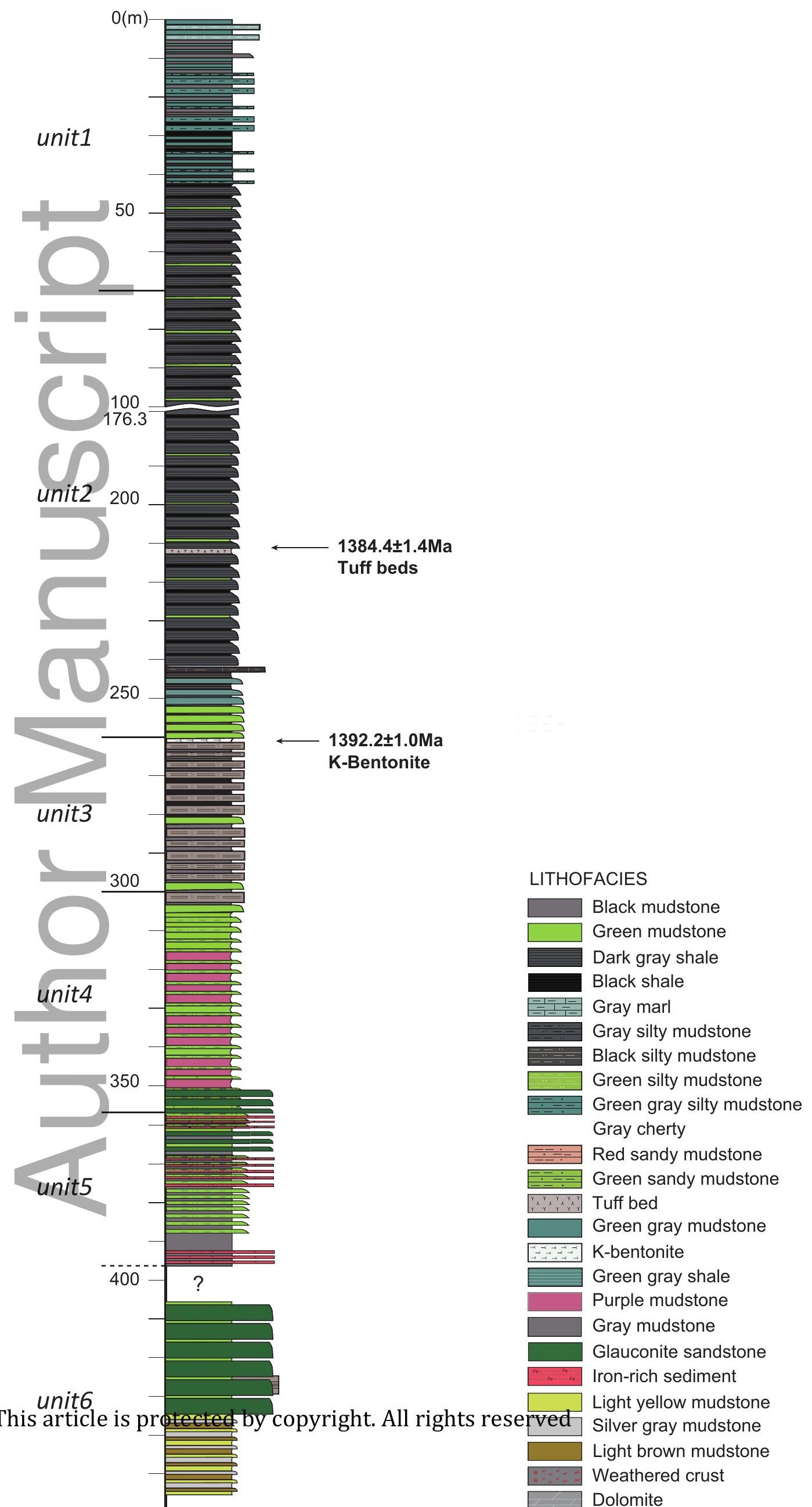




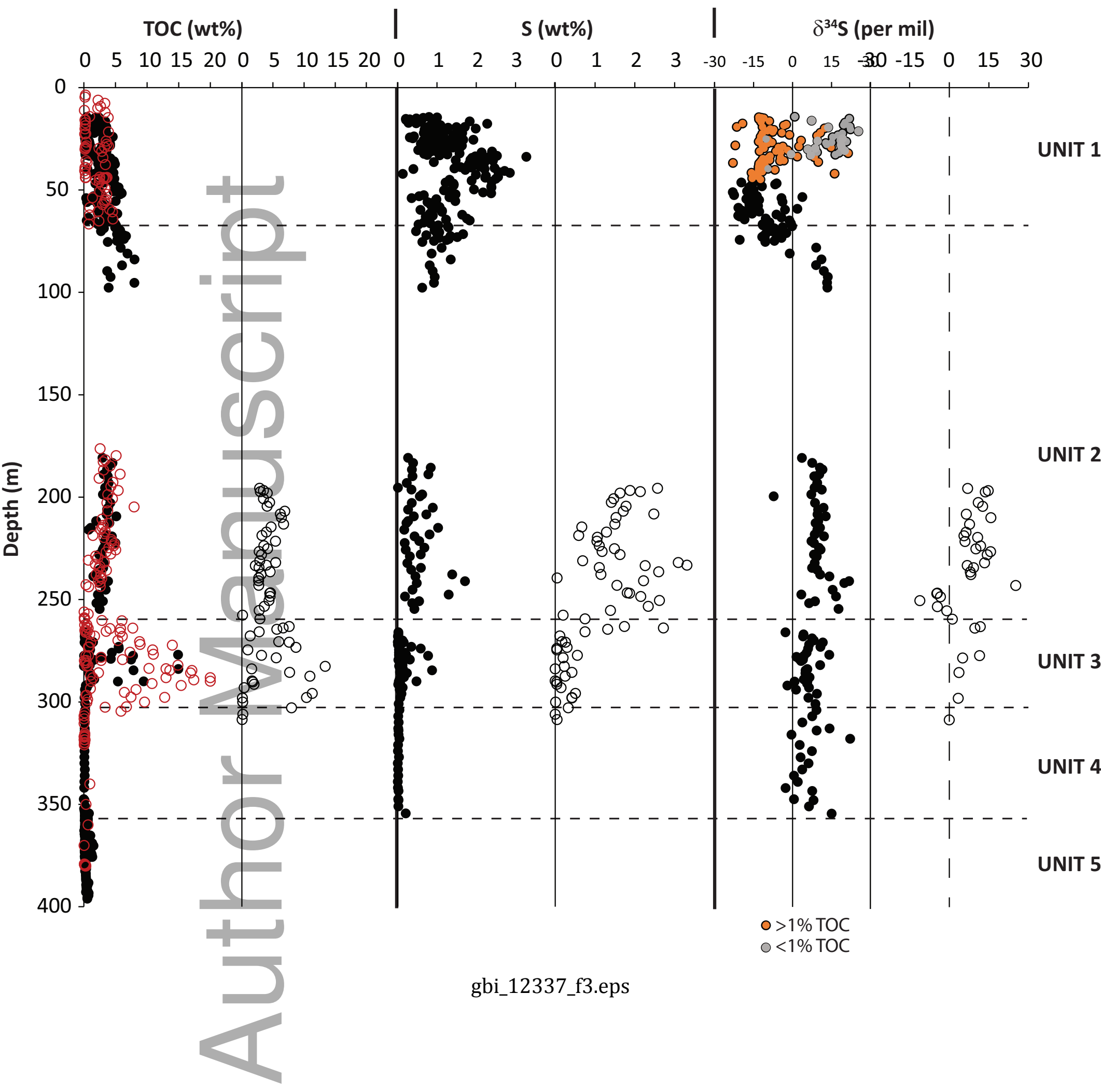

This article is protected by copyright. All rights reserved 


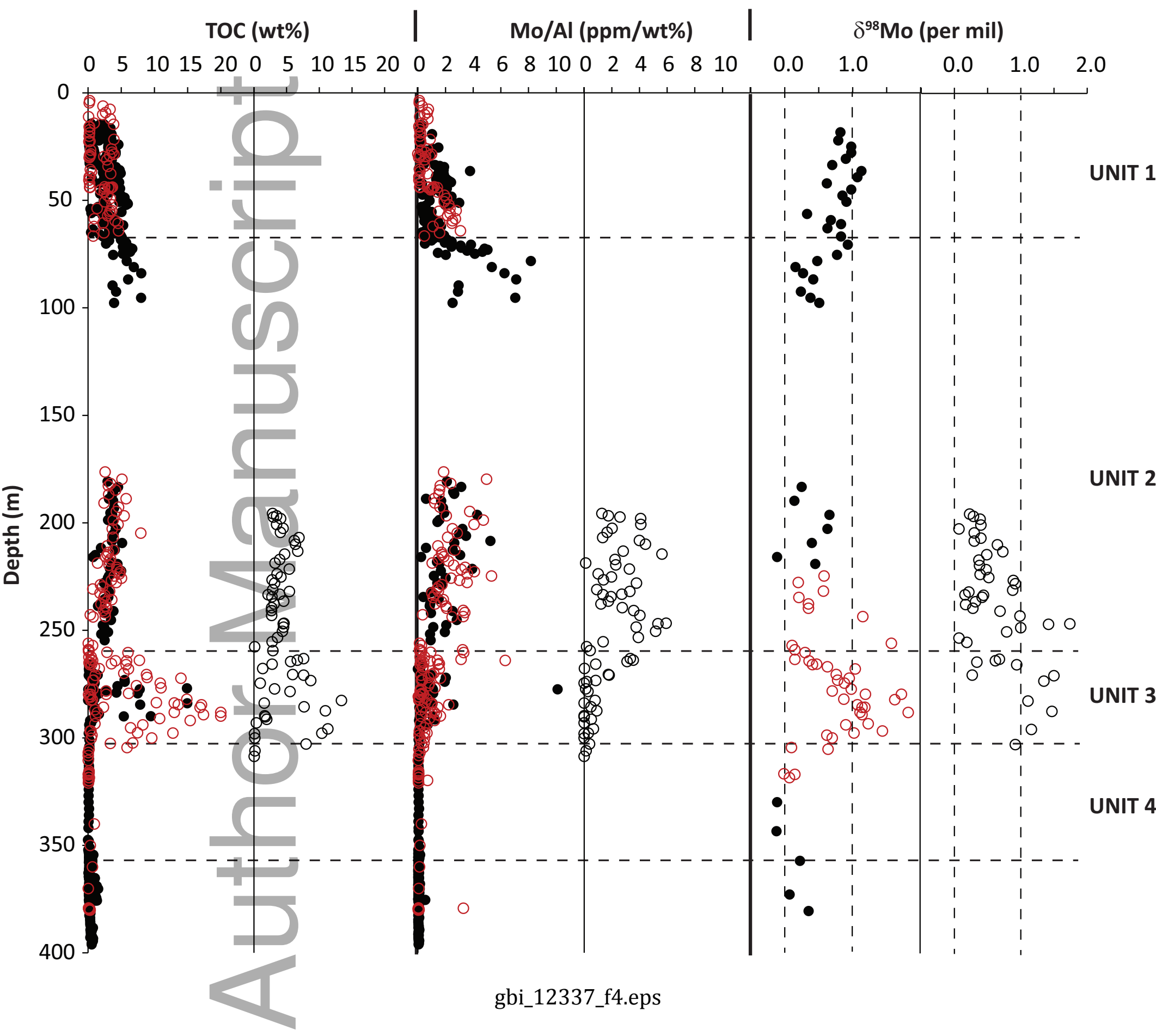

This article is protected by copyright. All rights reserved 


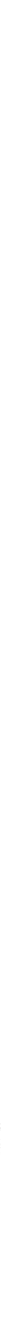

gbi_12337_f6.eps

This article is protected by copyright. All rights reserved 

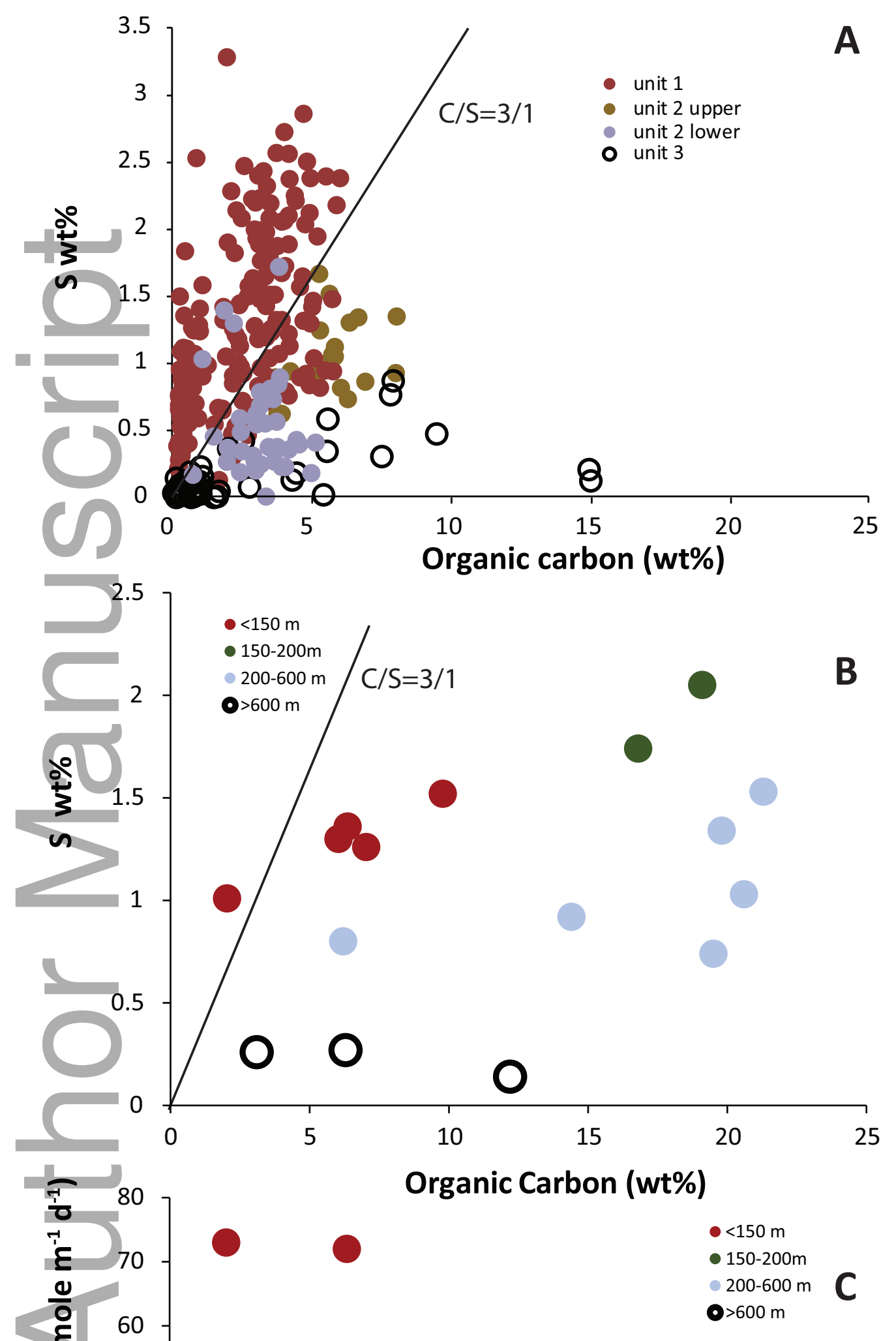

This $\Psi_{t i c l e}^{20}$ is protected by copyright. All rights reserved

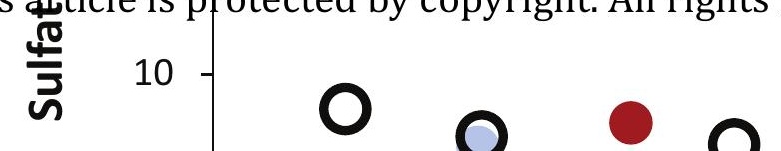




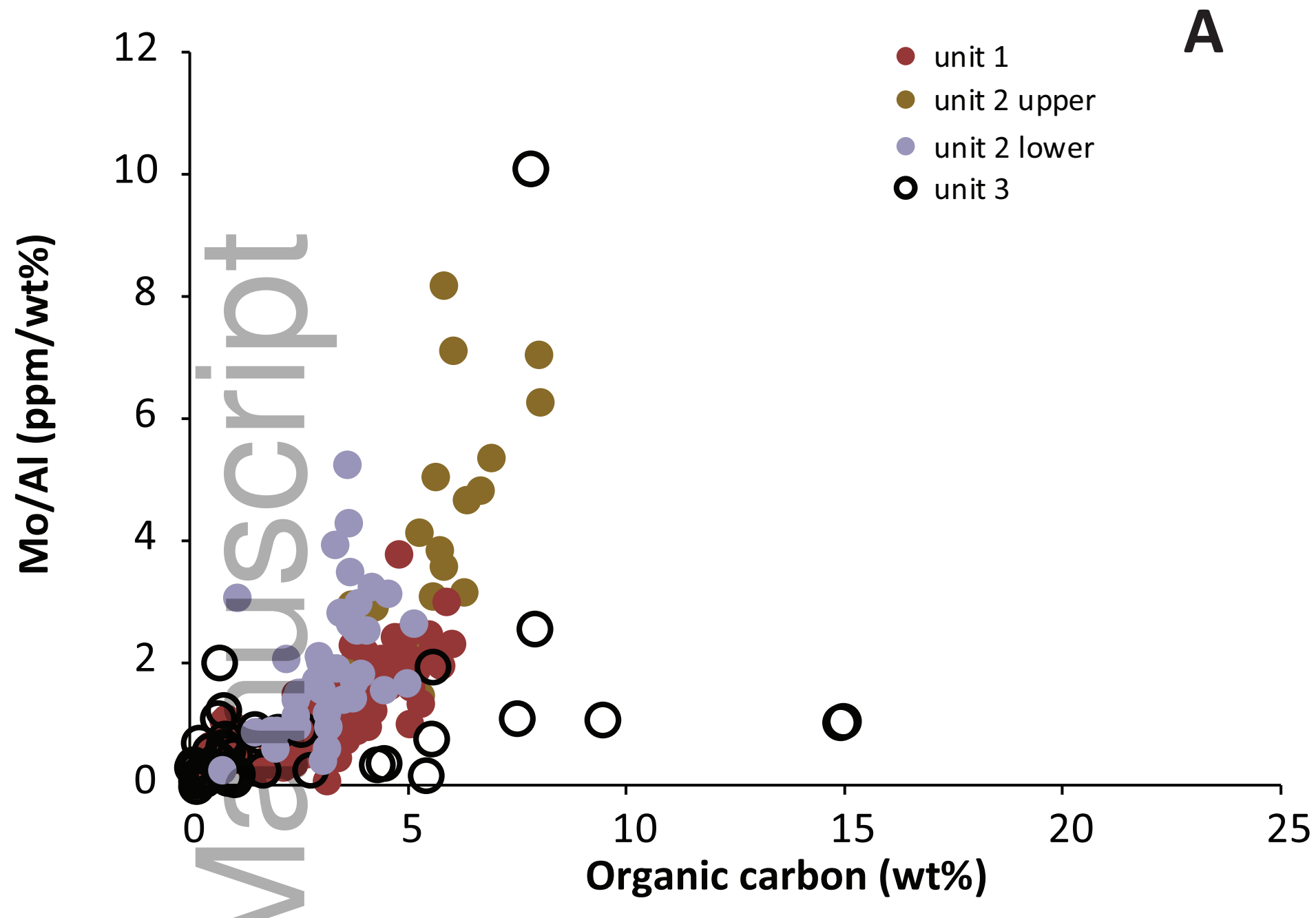

B

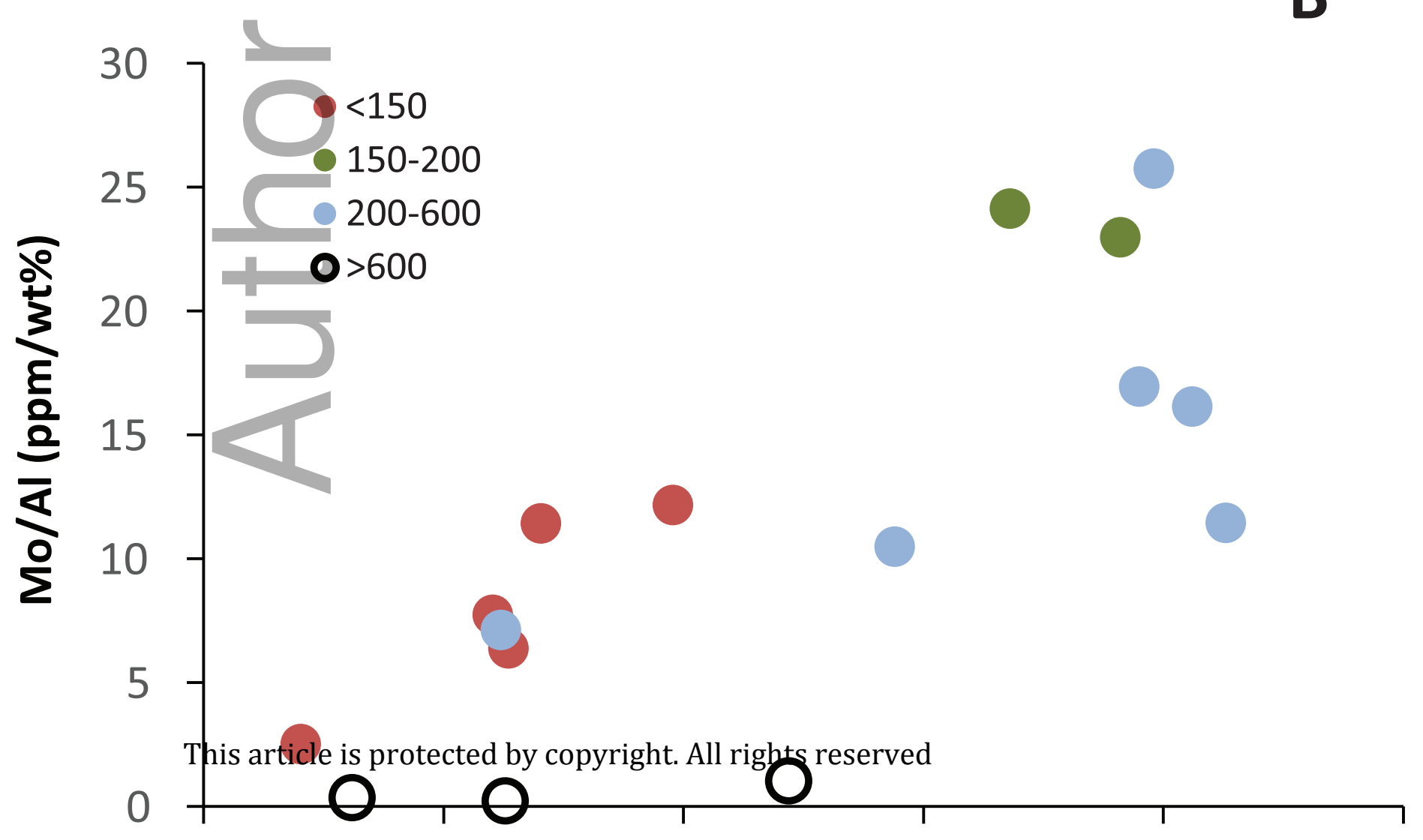


